University of Nebraska - Lincoln

DigitalCommons@University of Nebraska - Lincoln

2010

\title{
Interspecific Relationships among Growth, Mortality and Xylem Traits of Woody Species from New Zealand
}

\author{
Sabrina E. Russo \\ University of Nebraska - Lincoln, srusso2@unl.edu \\ Kerry L. Jenkins \\ University of Cambridge, Cambridge, UK \\ Susan K. Wiser \\ Landcare Research, Lincoln New Zealand \\ Maria Uriarte \\ Columbia University, mu2126@columbia.edu \\ Richard P. Duncan \\ Lincoln University, Lincoln New Zealand, Richard.Duncan@lincoln.ac.nz \\ See next page for additional authors
}

Follow this and additional works at: https://digitalcommons.unl.edu/bioscifacpub

Part of the Life Sciences Commons

Russo, Sabrina E.; Jenkins, Kerry L.; Wiser, Susan K.; Uriarte, Maria; Duncan, Richard P.; and Coomes, David A., "Interspecific Relationships among Growth, Mortality and Xylem Traits of Woody Species from New Zealand" (2010). Faculty Publications in the Biological Sciences. 161.

https://digitalcommons.unl.edu/bioscifacpub/161

This Article is brought to you for free and open access by the Papers in the Biological Sciences at DigitalCommons@University of Nebraska - Lincoln. It has been accepted for inclusion in Faculty Publications in the Biological Sciences by an authorized administrator of DigitalCommons@University of Nebraska - Lincoln. 


\section{Authors}

Sabrina E. Russo, Kerry L. Jenkins, Susan K. Wiser, Maria Uriarte, Richard P. Duncan, and David A. Coomes 
Published in Functional Ecology 24 (2010), pp. 253-262; doi: 10.1111/j.1365-2435.2009.01670.x

Copyright () 2010 Sabrina E. Russo, Kerry L. Jenkins, Susan K. Wiser, Maria Uriarte, Richard P. Duncan, and David A. Coomes; published by Wiley-Blackwell. Used by permission.

Submitted January 24, 2009; accepted October 27, 2009.

\title{
Interspecific Relationships among Growth, Mortality and Xylem Traits of Woody Species from New Zealand
}

\author{
Sabrina E. Russo, ${ }^{1}$ Kerry L. Jenkins, ${ }^{1}$ Susan K. Wiser, ${ }^{2}$ Maria Uriarte, ${ }^{3}$ \\ Richard P. Duncan, ${ }^{2,4}$ and David A. Coomes ${ }^{1,2}$ \\ 1. Forest Ecology and Conservation Group, Department of Plant Sciences, \\ University of Cambridge, Cambridge, UK \\ 2. Landcare Research, Lincoln New Zealand \\ 3. Department of Ecology and Evolution, Columbia University, New York, NY, USA \\ 4. Bio-Protection Research Centre, Lincoln University, Lincoln New Zealand \\ Corresponding author - S. E. Russo (as of 2010): School of Biological Sciences, \\ University of Nebraska-Lincoln, Lincoln, Nebraska, USA; srusso2@unl.edu
}

\begin{abstract}
1. Wood density is considered a key functional trait influencing the growth and survival of woody plants and has been shown to be related to a slow-fast rate-of-living continuum. Wood density is, however, an emergent trait arising from several vascular properties of wood, including the diameter and frequency of xylem conduits.

2. We aimed to test the hypotheses that there is a set of inter-related trade-offs linked to the different functions of wood, that these trade-offs have direct consequences for tree growth and survival and that these trade-offs underlie the observed correlations between wood density and demographic rates. We evaluated the covariation between xylem anatomical traits among woody species of New Zealand and whether that covariation had the potential to constrain variation in wood density and demographic rates.

3. Several xylem traits were strongly correlated with each other, but wood density was not correlated with any of them. We also found no significant relationships between wood density and growth or mortality rate. Instead, growth was strongly related to xylem traits associated with hydraulic capacity (conduit diameter and a conductivity index) and to maximum height, whereas mortality rate was strongly correlated only with maximum height. The diameter and frequency of conduits exhibited a significant negative relationship, suggesting a trade-off, which restricted variation in wood density and growth rate, but not mortality rate.

4. Our results suggest, for woody species in New Zealand, that growth rate is more closely linked to xylem traits determining hydraulic conductance, rather than wood density. We also found no evidence that denser woods conferred higher survival, or that risk of cavitation caused by wide conduits increased mortality.

5. In summary, we found little support for the idea that wood density is a good proxy for position along a fast-slow rate-of-living continuum. Instead, the strong, negative relationship between vessel diameter and frequency may constrain the realized diversity of demographic niches of tree species in New Zealand. Trade-offs in function therefore have the potential to shape functional diversity and ecology of forest communities by linking selection on structure and function to population-level dynamics.
\end{abstract}

Keywords: functional traits, New Zealand forests, phylogenetic comparative methods, tradeoffs, tree maximum height, tree diameter growth rate, tree mortality rate, vessel and tracheid properties, wood density

\section{Introduction}

Wood density is regarded as a key functional trait influencing the growth and mortality of woody plants. Wood density is conventionally defined as dry mass divided by fresh volume, so that, all else being equal, woody species producing denser wood should have slower volume growth than species producing lighter wood. This prediction is supported 
by studies in tropical forests showing that wood density is negatively correlated with diameter growth rate across species (Putz et al. 1983; Enquist et al. 1999; King et al. 2006b; Osunkoya et al. 2007). Wood density in angiosperms is related to the thickness and number of fibers per unit crosssectional area (Carlquist 1975). As fibers convey strength to wood, denser wood is more resistant to damage from falling debris (Poorter et al. 2008), wind storms and buckling under the tree's own weight (Putz et al. 1983; Lawton 1984; King 1986), and wood-boring arthropods and pathogens (Bultman \& Southwell 1976), which are significant causes of tree mortality. Consequently, studies in tropical forests also report a positive correlation between wood density and survival rate across species (Putz et al. 1983; King et al. 2006b Osunkoya et al. 2007). Thus, several lines of evidence suggest that wood density is related to position along a slowfast rate-of-living continuum: species with denser wood tend to have slower growth, higher survival and greater shade tolerance, whereas species with lighter wood tend to have faster growth, lower survival and lower shade tolerance (Smith \& Tumey 1982; Lawton 1984; King 1986; King et al. 2005; Chave et al. 2006; King et al. 2006b). The aim of this study is to examine the extent to which trade-offs in function involving wood density and xylem traits are in fact related to growth and mortality rates of woody plant species.

Wood density, is an emergent feature of wood that results from a combination of several xylem traits, including conduit (vessel or tracheid) diameter and frequency and fiber density. Wood density tends to increase with decreasing conduit diameter and frequency and with increasing fiber density (Carlquist 1975). Although high wood density may confer a direct survival advantage, the often-reported relationship between wood density and growth rate could arise from other xylem traits that are correlated with density, but are linked more directly to hydraulic attributes of wood. The diameter of angiosperm vessels, for example, is positively correlated with growth rate, because wider vessels allow greater rates of transpiration and photosynthesis (Castro-Diez et al. 1998; Denne, Cahalan \& Aebischer 1999; Brodribb \& Feild 2000; Stratton, Goldstein \& Meinzer 2000). The wider vessels often associated with lighter woods can, however, increase the risk of cavitation (breakage of the water column within the xylem), causing water conduction to decline if cells become embolized (air-filled) and leading, in extreme cases, to tree death (Tyree \& Sperry 1989; Tyree, Davis \& Cochard 1994; Davis, Sperry \& Hacke 1999; Hacke et al. 2001). A trade-off between hydraulic conductance and resistance to embolism may therefore underlie the relationship that wood density has with growth and mortality rate, although a comparative phylogenetic analysis did not find evidence for this trade-off (Maherali, Pocknan \& Jackson 2004).

Negative relationships between species' xylem traits can arise when they are under opposing selection due to tradeoffs in function related to hydraulic conductance, cavitation-risk and mechanical constraints (Carlquist 1975; Baas et al. 2004; Sperry, Meinzer \& McCulloh 2008; Chave et al. 2009). For example, an increase in wood density should reduce the space in the stem that is available to the hydrau- lic pathway (lumen fraction), leading to higher resistance to water conductance and reduced photosynthetic capacity (Carlquist 1975). Lumen fraction itself is determined by conduit diameter and frequency, which are often found to be negatively correlated: if conduits are too wide and frequent, they may be easily embolized, but if they are too narrow and infrequent, hydraulic capacity is severely reduced (Chave et al. 2009). Furthermore, given stem diameter and wood of a particular density and modulus of elasticity, there is a critical height above which a tree will buckle under its own weight, and this biomechanical limitation is considered to be a determinant of a tree's maximum height (Greenhill 1881; McMahon 1973; King 1981). Consistent with these trade-offs in function, tree species with taller maximum heights generally have lighter wood to reduce buckling risks (Thomas 1995) and faster growth and higher mortality rates (King, Davies \& Supardi 2006a).

Our aim in this study is to test the hypotheses that there is a set of inter-related trade-offs linked to the different functions of wood, that these trade-offs have direct consequences for tree growth and survival and that these tradeoffs underlie the observed correlations between wood density and demographic rates. Specifically, we evaluated the covariation between xylem anatomical traits among species and whether that covariation had the potential to constrain variation in higher-order traits, such as wood density and demographic rates. To our knowledge, this is the first large-scale comparative test of these ideas outside of tropical forests. We related wood densities and xylem properties to data on growth and mortality rates collected over 36 years in natural forests of New Zealand. To account for other factors known to influence demographic rates, we modeled growth and mortality for juvenile and adult trees of each species, taking account of local neighborhood interactions, which enabled us to relate wood densities and vascular properties to estimates of species' maximum growth and survival capacities.

\section{Materials and methods}

\section{Wood Properties}

In New Zealand forests are dominated by Nothofagus (Southern beech; Nothofagaceae) and conifer (Podocarpaceae and Cuppressaceae) species, in association with a diverse group of hardwoods (Wardle 1991). We selected 39 species for study (34 angiosperms and 5 podocarps; Table S1), comprising all species for which we could obtain data on wood properties. We measured the following wood properties for each species: wood density $\left(\mathrm{g} \mathrm{cm}^{-3}\right)$, conduit (vessel or tracheid) diameter $(\mu \mathrm{m})$ and number of conducting cells (vessels or tracheids) per $\mathrm{mm}^{2}$ (conduit frequency). Wood density was measured using air-dried wood samples archived in the Allan Herbarium at Landcare Research, New Zealand: each sample (one per species) was weighed to $\pm 0.001 \mathrm{~g}$ and its volume measured by submerging it into a container of water on a scale and measuring the change in recorded weight. The conventional method of calculating wood density is dry mass divided by fresh volume, rather than the dry volume used here. We compared our dry volume wood density estimates to fresh volume estimates using two independent data sets that shared species with our 
data set. The dry and fresh volume estimates were significantly correlated (D. A. Coomes, unpublished data: $N=12 ; r$ $=0.56, P<0.05$; I. A. Payton, unpublished data: $N=28, r=0.71$, $P<0.05$; Pearson correlations). Wood densities of smaller-statured species (shrubs and some small trees) were largely sampled from branch samples, whereas those for canopy trees were from trunk cores.

The remaining wood properties were measured from published scanning electron micrographs (SEM) of each species (one image per species) taken using a Cambridge SIIa microscope (Meylan \& Butterfield 1978). The wood samples used for these micrographs were collected from mature trees growing naturally in their native habitats within their normal distributional range. For most species, cores were removed at waist height from the outside of large trees following bark removal using a 25-mm diameter core borer, so that the micrographs are representative of sapwood. For smaller-stature trees and shrubs, coring was not possible without excessive damage to the tree, and so wood samples taken from branch segments were used (B. Butterfield, pers. comm.). A small cube (c. $5 \mathrm{~mm}$ on a side) with cleanly cut surfaces was prepared from each wood sample, and SEMs were made from the transverse face. These published SEM images were scanned into a computer, and vessel and tracheid diameters and numbers were measured from these images using ImageJ software (Abramoff, Magelhaes \& Ram 2004). The diameters of all conduits fully visible on each micrograph were averaged, thereby accounting for differences between early-and latewood vessels. We developed a conductivity index based on the Hagen-Poiseuille law of laminar flow, which states that the hydraulic conductivity per unit pressure gradient of a bundle of pipes $\left(k_{\mathrm{h}}\right)$ equals $[\pi \rho / 128 \eta]\left[\Sigma d_{i}^{4}\right]$ for $i=1$ to $n$ conduits in the bundle, where $\rho$ is the density of the fluid, $d_{i}$ is the diameter of each conduit in the bundle and $\eta$ is the viscosity of the fluid. Formally, $k_{\mathrm{h}}$ is the proportionality constant between flux and the pressure gradient causing the flux (Tyree \& Ewers 1991). The conductivity index that we used was the product of the number of conduits per $\mathrm{mm}^{2}$ and the fourth power of the weighted mean diameter of conduits $\left(\mu \mathrm{m}^{2}\right)$. We estimated lumen fraction $(F)$ as the product of conduit area and frequency. The estimated maximum height attained for each of the species for which demographic rates were estimated was collected from the literature (Wardle 1991; Poole \& Adams 1994; Wilson 1994) and the New Zealand Plants Databases (Landcare Research 2006).

Wood traits can vary substantially within trees and species (Nogueira et al. 2005; Nogueira, Fearnside \& Nelson 2008), although wood densities estimated from stem cores and branch segments can be highly correlated (Swenson \& Enquist 2008). Nevertheless, this variation is often overwhelmed by interspecific differences, which we aimed to quantify. In our study, analyses restricted to data from canopy trees vs. shrubs and small trees largely showed the same patterns as analyses using all species; therefore, the latter are presented here.

\section{Estimates of Mean Observed Growth and Mortality Rates}

Growth and mortality rates of woody plant species were estimated from permanent plot data archived in the National Vegetation Survey (NVS) databank (Wiser, Bellingham \& Burrows 2001). We used species with at least 100 trees, which amounted to 54 and 59 species for growth and mortality rates respectively (Table S1). This increased our sample size from 39 species (for which we had wood traits) to 54 and 59 species for examining relationships between maximum height and growth and mortality rates respectively. Between 1969 and 2004, permanently marked $20 \times 20 \mathrm{~m}\left(400 \mathrm{~m}^{2}\right)$ plots were established in a stratified random design in watersheds throughout New Zealand. Each $20 \times 20$ plot was divided into $16.5 \times$ $5 \mathrm{~m}$ quadrats. Within each plot, each woody stem $>30 \mathrm{~mm}$ in diameter at breast height (diameter) was tagged, identified to species, and its diameter to the nearest $1 \mathrm{~mm}$ and quadrat were recorded. We extracted data for those plots that had been measured at least twice.

The observed mean diameter growth rate $\left(G ; \mathrm{mm}\right.$ year $\left.{ }^{-1}\right)$ of a species was calculated as the change in diameter $(D ; \mathrm{mm})$, divided by the intercensus interval ( $t$; years): $G=\left(D_{t}-D_{0}\right) / t$. We estimated the instantaneous mortality rate $\lambda$ (year-1) of each species using the survival function (the probability that a tree will survive to time $t, S(t)=\mathrm{e}^{-\lambda t}$ assuming that $\lambda$ remained constant over time and did not vary among individuals (Appendix S1). We estimated $\lambda$ by minimizing the negative $\log$ of its likelihood function (Appendix S1). For species that had at least 100 juvenile or adult trees, we estimated growth and mortality rates separately (juveniles: $30-200 \mathrm{~mm}$ and adults: $\geq 200 \mathrm{~mm}$ in diameter).

\section{Growth Rates of Trees with Few Tall Neighbors}

We modeled instantaneous diameter growth rates $(\mathrm{d} D / \mathrm{d} t)$ of individual trees as a function of diameter $(D)$, temperature $(T$ in kelvin) and the basal area of taller trees in the immediate neighborhood $(A)$, using the following relationship (Coomes \& Allen 2007):

$$
\frac{\mathrm{d} D}{\mathrm{~d} t}=\left[\frac{\beta}{1+\beta \mathrm{e}^{\lambda_{3} A} / \lambda_{2}}\right]\left[\mathrm{e}^{\frac{E\left(T-T_{0}\right)}{k T T_{0}}}\right]\left[D^{\alpha}\right] .
$$

(Equation 1)

The term within the third set of brackets specifies the size dependence of growth assuming that growth is a power function of diameter (Enquist et al. 1999; Muller-Landau et al. 2006). The terms within the second set of brackets model the temperature dependence of growth using the Arrhenius-Boltzmann equation, where $E$ is the activation energy of metabolic processes (c. $0.65 \mathrm{eV}), k$ is the Boltzmann constant $\left(8.62 \times 10^{-5} \mathrm{eV} \mathrm{K}^{-1}\right)$ and $T_{0}$ is the mean temperature across all plots in the NVS data (282 $\mathrm{K})$. The terms within the first set of brackets define the influences of neighboring trees on growth: we used a nonlinear function that assumes that the amount of light intercepted by taller neighbors is exponentially related to their summed basal area (based on the Beer-Lambert law and the Michealis-Menton function, assuming that the basal area is directly proportional to leaf area; Coomes \& Allen 2007). We calculated whether trees were taller than the target tree by estimating the height of each tree from its diameter, using species-specific diameter-height allometries (Russo, Wiser \& Coomes 2007). Based on this neighborhood function, a tree growing at average temperature without competitors would have a growth rate of $\beta /\left(1+\beta / \lambda_{2}\right) D^{a}$. We estimated the basal area of taller neighbors of each tree in the central four $5 \times 5 \mathrm{~m}$ quadrats (these are the target trees for which growth was modeled) using the sum of the basal areas of taller trees in the nine quadrats (comprising a $15 \times 15 \mathrm{~m}$ area) surrounding and including the quadrat in which the target tree was located (Coomes \& Allen 2007).

Integration of the growth function gives an expression predicting a tree's diameter at time $t\left(D_{t}\right)$ from its initial diameter $\left(D_{0}\right.$; Equation 3 of Appendix S1); it was this integrated function that was fit to our data set. We assumed that individual deviations from the predicted final diameter for tree $i, \varepsilon_{i}$, were log- 
normally distributed and depended on the length of the intercensus interval in $y, t_{i}$, which varied among trees, thereby scaling error variance by time. For each species, we minimized the negative log-likelihood function of this growth model using the Nelder-Mead simplex search algorithm in R (The R Core Development Team 2006). The fitted values for parameters in Equation 1 were then used to predict each species' growth rate under standardized size and neighborhood conditions. We selected values of $A$ in the 15th percentile of neighborhood overtopping basal area (lower percentiles were strongly influenced by outliers). We made these predictions for juveniles $(D=100$ $\mathrm{mm}$ and $\left.A=25 \mathrm{~m}^{2} \mathrm{ha}^{-1}\right)$ and adults $\left(D=200 \mathrm{~mm}\right.$ and $A=5 \mathrm{~m}^{2}$ $\left.\mathrm{ha}^{-1}\right)$, using the mean temperature across all trees in the data.

\section{Mortality Rates of Trees with a High Density of Overtopping Neighbors}

We modeled individual mortality probability in the time interval during which a tree was observed as a function of its diameter $(D)$ and neighborhood $(A)$ at the beginning of that interval (Appendix S1). A tree's instantaneous mortality rate was modeled as:

$$
m(D)=\left[\delta D^{\eta}\right]\left[\frac{1}{1+\lambda_{1} A^{\lambda_{2}}}\right] .
$$

The term in the first and second sets of brackets describe the size dependence of mortality and the effects of neighbors respectively. The basal area of taller neighbors in surrounding subplots was calculated in the same way as for the growth model; the two parameters were constrained such that $\lambda_{1}>0$ and $\lambda_{2}<$ 0 (Coomes \& Allen 2007). This approach assumes that over the census interval during which mortality was estimated, a tree grows with respect to its diameter following the predicted relationship for its species, as fit in Russo, Wiser \& Coomes (2007).

The parameters for each species were estimated by minimizing the negative log of the likelihood function of the survival function (Equations 6 and 7 in Appendix S1). Parameter estimates were then used to obtain the predicted instantaneous mortality rate of a tree with particular neighborhood and diameter values. We used values of $A$ in the 85th percentile of neighborhood basal area of overtopping trees for juveniles and adults. We compared mortality of juveniles at $D=$ $100 \mathrm{~mm}$ and $A=80 \mathrm{~m}^{2} \mathrm{ha}^{-1}$ and adults at $D=200 \mathrm{~mm}$ and $A=$ $64 \mathrm{~m}^{2} \mathrm{ha}^{-1}$ at the mean temperature across all trees in the data.

\section{Statistical and Phylogenetic Methods}

Pearson correlation tests were used to quantify relationships among wood properties, and between wood properties and demographic rates, both across species and using phylogenetically independent contrasts (PICs) (Felsenstein 1985). Variables were log-transformed to improve normality. Because multiple tests of correlation were performed, we report calculated probabilities and indicate whether each would be considered statistically significant after a correction for multiple comparisons (Holm 1979).

We assembled a hypothesis of the phylogenetic relationships among the 59 species in our data using an unpublished phylogeny (S. J. Wagstaff, A. Wilton, M. Cochrane and G. Barker, unpublished manuscript), published genus-level phylogenies and sister-taxon relationships based on currently accepted alpha taxonomy of woody plant species of New Zealand (Figure S1). As the phylogenetic tree was a composite from multiple sources, we lacked data on branch lengths and so used Grafen's branch lengths (Grafen 1989). Our phylogeny was not fully bifurcating for the genera Coprosma and Olearia. As detailed in Appendix S2, for analyses involving polytomies (between maximum height and juvenile mean observed growth and mortality rates), we generated 1,000 random resolutions of the phylogenetic tree, calculated independent contrasts and performed a Pearson correlation for each. We report the mean correlation coefficient and the maximum probability value from these 1,000 random trees (distributions are shown in Figure S2). We used the R package ape for all phylogenetic comparative analyses.

We examined how wood vascular properties that were found to be significantly and strongly negatively correlated [i.e. conduit diameter $(D)$ and frequency $(N)$; Figure 1a] jointly affected wood density and growth and mortality rates of angiosperms using a statistical model. A trade-off between vessel diameter and frequency implies that certain combinations of these traits are not favored in nature, which could limit the possible variation in wood density or demographic rates. To examine this possibility, we fit a statistical model:

$$
\log (R)=a \log (N)+b \log (D)+c
$$

(Equation 3)

where $R$ is either wood density or mean juvenile observed growth or mortality rate of tree species and $a, b$ and $c$ were fitted parameters. A strong relationship between predictors can result in multicollinearity, which does not reduce the predictive power of the overall model, but can reduce the interpretability of individual parameter estimates. We therefore restricted interpretation to the overall model fit, and took a significant fit to imply that the trade-off between conduit diameter and frequency constrained variation in the response variable. This model was fit using two regression methods, ordinary least squares (OLS) and phylogenetic generalized least squares (PGLS) (Martins \& Hansen 1997; Freckleton, Harvey \& Pagel 2002; Appendix S3), and their relative fits to the data were compared using Akaike's information criterion (AIC). Among alternatives tested, the AIC was always lower for the OLS model, implying a weak phylogenetic signal, and so only results from the OLS models are presented (Table S2).

\section{Results}

\section{Relationships among Wood Traits}

Several pairs of wood properties were significantly correlated among New Zealand's woody species, both across species and using PICs (Figure 1, Figure S3). Across species, lumen fraction was the only xylem trait that had any relationship with wood density, but the correlation was weak and non-significant (Figure S3d). The correlation was stronger, however, when angiosperms were analyzed alone $(r=-0.44, P=0.0009, N=34)$. Species with higher conduit frequency had significantly narrower conduits (Figure S3a) and greater lumen fractions (Figure S3b). Higher conductivity indices were significantly associated with wider conduits (Figure S3c) and greater lumen fractions (Figure S3d).

Correlations based on PICs were consistent with those across species, with the exception of two correlations involving lumen fraction (Figure $1 \mathrm{~b}, \mathrm{~d}$ ). For conduit frequency, the significant correlation across species was driven primarily by the inclusion of podocarps: the relationship 

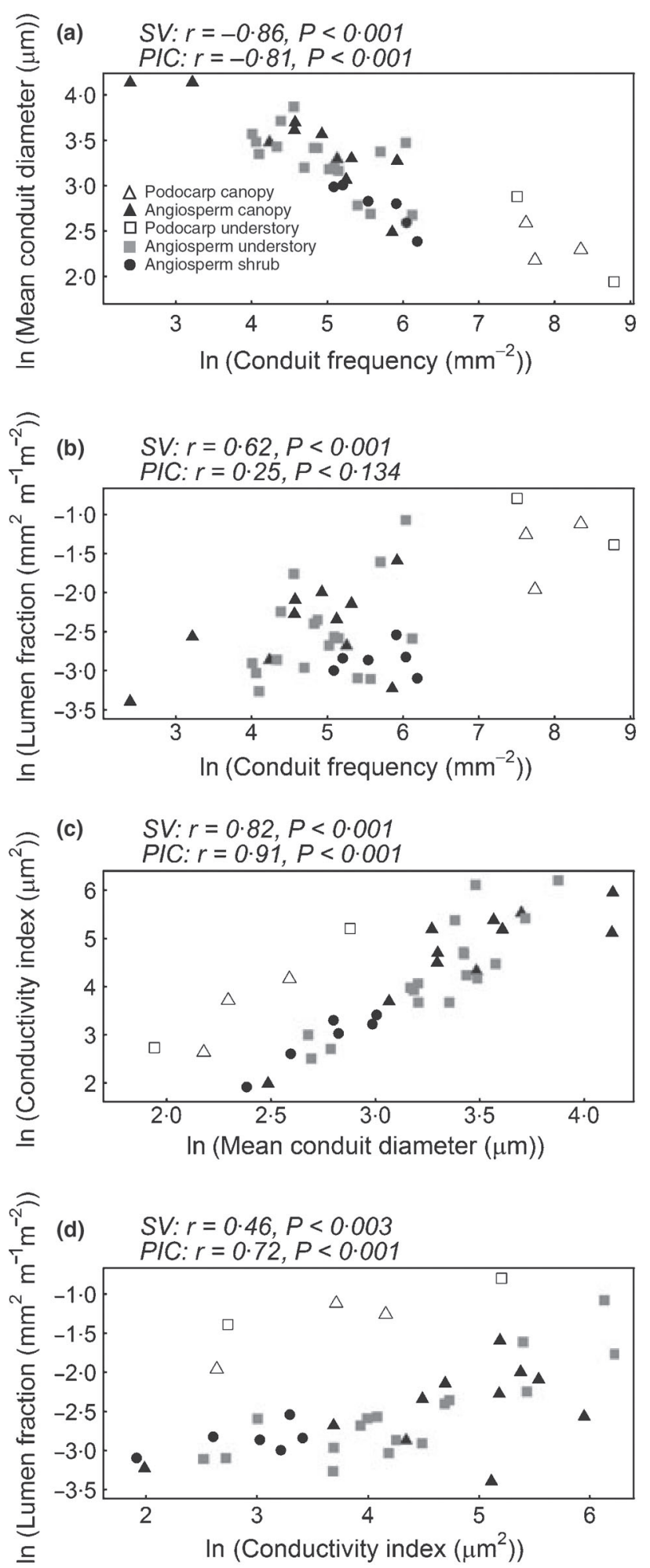

Figure 1. Statistically significant relationships, after correction for multiple comparisons, between the five wood properties of New Zealand tree species examined in this study: (a) mean conduit diameter and frequency, (b) lumen fraction and conduit frequency, (c) conductivity index and conduit diameter and (d) lumen fraction and conductivity index. Correlation statistics for species' values (SV) and phylogenetically independent contrasts (PICs) are above each panel. Relationships are plotted on natural log scales. Symbols: triangles, canopy trees; squares, understory trees; circles, shrubs; filled symbols, angiosperms; open symbols, conifers. See also Figure S3. was not significant across angiosperm species alone $(r=$ $0.28, P=0.113, N=34$ ), which was consistent with the results based on PICs. For conductivity index, the five podocarp species tended to maintain a higher lumen fraction at a given conductivity index than did angiosperms. When the podocarps were removed, the relationship was closer to the result based on PICs $(r=0.72, P<0.001, N=34)$.

Significant negative correlations among wood traits suggest the possibility of interspecific trade-offs between conduit diameter and frequency (Figure 1a), but not between conductivity index and wood density (Figure S3c), nor lumen fraction and wood density (Figure S3d). Based on our statistical model (Equation 3), c. $29 \%$ of the variation in wood density could be explained by vessel diameter and frequency, although after accounting for multiple comparisons, the model was not statistically significant $\left(F_{2,31}=6.467, P=0.004, R^{2}=0.29\right.$; Figure 2). Model comparison favored retention of both vascular properties in the model over a model with only vessel frequency or diameter $\left(\mathrm{AIC}_{\text {full }}=-23.51, \mathrm{AIC}_{\text {frequency }}=-20.55, \mathrm{AIC}_{\text {diameter }}=\right.$ $-14.41)$.

\section{Relationships among Wood Traits and Growth and Mortality Rates}

Across species, the observed mean juvenile growth rate was significantly correlated with predicted juvenile growth rate in high light. Similarly, the observed mean juvenile mortality rate was significantly correlated with predicted juvenile mortality rate in shade. The correlations were weaker for adult rates (Figure S4).

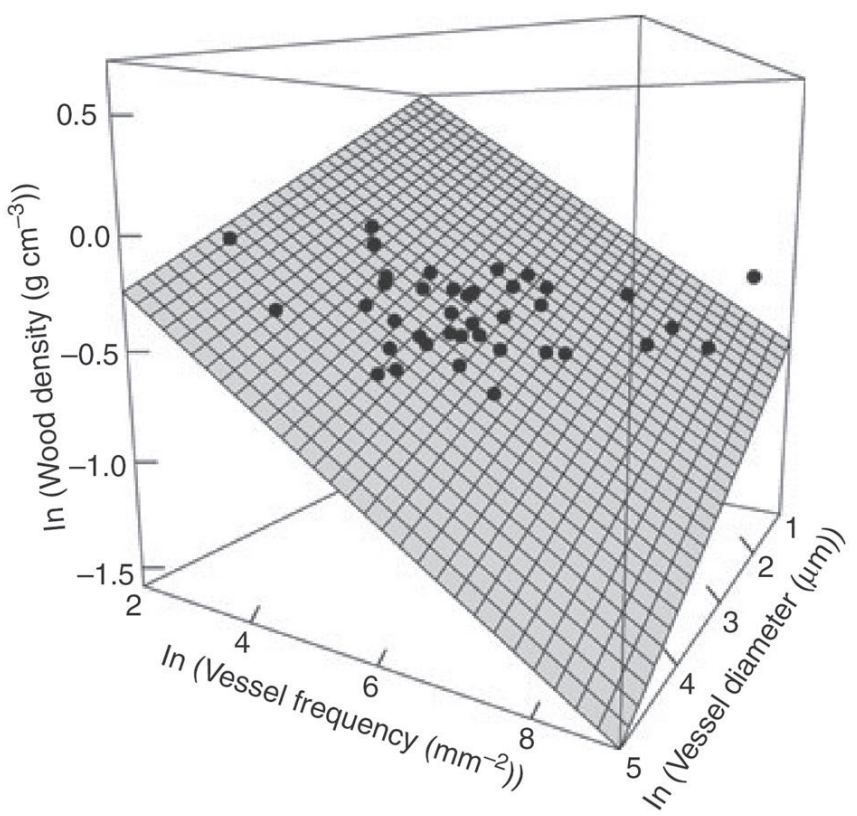

Figure 2. Relationship of wood density $\left(\mathrm{g} \mathrm{cm}^{-3}\right)$ with vessel frequency $\left(\mathrm{mm}^{-2}\right)$ and diameter $(\mu \mathrm{m})$ for New Zealand angiosperm tree species. Black points are observed values. The plane is a fitted surface based on Equation 3. All axes are plotted on natural log scales. 


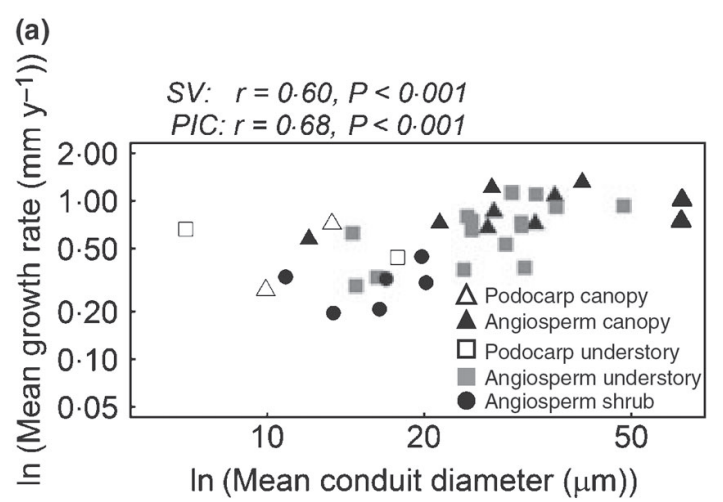

(b)

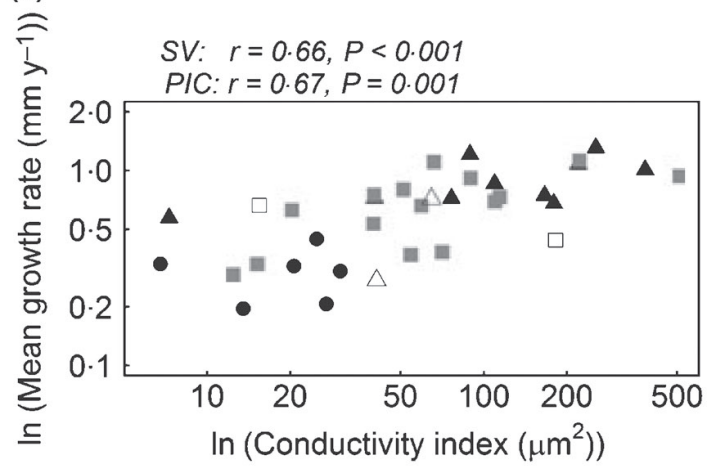

Figure 3. Statistically significant relationships, after correction for multiple comparisons, between the five wood properties examined in this study with juvenile growth rates of New Zealand tree species: observed mean diameter growth rate and (a) conduit diameter and (b) conductivity index. See Materials and methods for details. Symbols: triangles, canopy trees; squares, understory trees; circles, shrubs; filled symbols, angiosperms; open symbols, conifers. Correlation statistics for species' values (SV) and phylogenetically independent contrasts (PICs) are above.

Across species, juvenile (30-200 $\mathrm{mm}$ in diameter) growth rates were significantly correlated with several wood properties, but not with wood density (Figure S5). A faster growth rate was significantly associated with wider conduit diameter (Figure 3a) and larger conductivity index (Figure $3 b$ ). Across species, the relationship between growth and lumen fraction was not significant (Figure S5e), which was likely due to its nonlinearity. Indeed, the correlation across species using only angiosperms was stronger, but still not significant $(r=0.45, P=0.010, N=30)$. For adults $(\geq 200 \mathrm{~mm}$ in diameter), no estimate of growth rate was significantly correlated with any wood trait (Table S1). Similarly, across species, neither predicted mortality rate in shade nor observed mortality rate of juveniles or adults was significantly correlated with any wood trait (Table S3, Figure S6). Correlations between wood traits and growth and mortality rates based on PICs paralleled the results across species.

We evaluated the extent to which strong negative relationships between wood traits might constrain interspecific variation in growth and mortality rates. For the trade-off between vessel diameter and frequency, the model explained a substantial portion of interspecific variation in growth rates $\left(F_{2,28}=16.3, P<0.001,=0.54\right.$; Figure $\left.4 \mathrm{a}\right)$, but $R^{2}$ not mortality rates $\left(F_{2,29}=0.2436, P=0.785, R^{2}=0.02\right.$; Figure $4 b)$.
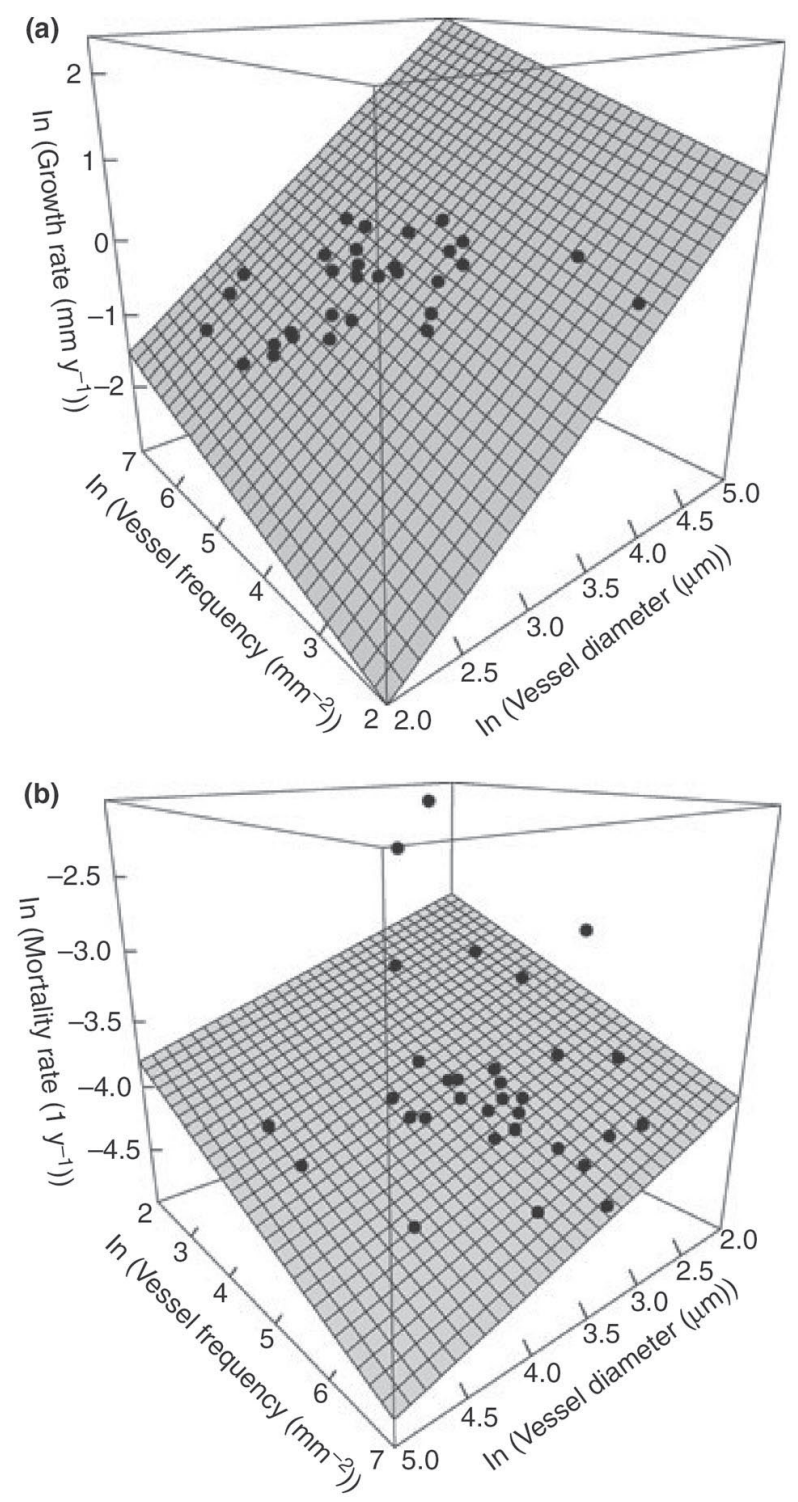

Figure 4. Relationships of juvenile observed mean growth (a) and mortality $(b)$ rates with vessel frequency $(N ; \mathrm{mm})$ and diameter $(D ; \mu \mathrm{m})$ for New Zealand angiosperm tree species. Black points are observed values. Planes are fitted surfaces based on a parameter estimate from the statistical model in Equation 3. Relationships are plotted on natural log scales. Note the change in orientation of the two horizontal axes.

\section{Maximum Height as an Axis of Differentiation among Species}

Maximum height was positively correlated with wood traits associated with hydraulic conductance, but there was no relationship with wood density (Figure 5, Figure S7). Analyses across species and using PICs were consistent, except for the relationship of maximum height with conduit frequency (Figure 5a). The difference was largely due to podocarps with tall maximum heights, but narrow, frequent tracheids. Across angiosperm species alone, the relationship between conduit frequency and maximum height was stronger $(r=-0.31, P=0.072, N=34)$ and more consistent with the result based on PICs. Based on analyses across 

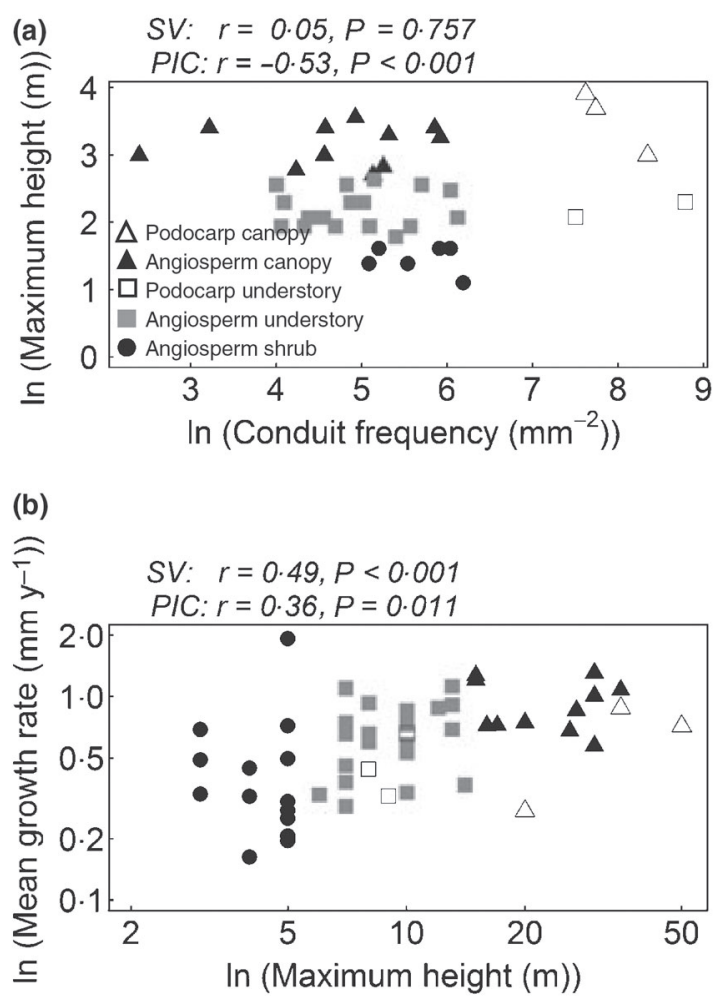

Figure 5. Statistically significant relationships, after correction for multiple comparisons, of maximum tree height with the five wood properties examined in this study and juvenile growth and mortality rates of New Zealand tree species: (a) maximum height and conduit frequency and (b) juvenile observed mean growth rate and maximum height. See "Demographic data and analytical methods" for details. Symbols: triangles, canopy trees; squares, understory trees; circles, shrubs; filled symbols, angiosperms; open symbols, conifers. Correlation statistics for species' values (SV) and phylogenetically independent contrasts (PICs) are above each panel. Relationships are plotted on natural log scales. Note that in (b), the mean correlation coefficient and maximum probability for PICs are based on 1,000 random resolutions of the phylogeny (Appendix S2, Figure S2). See also Figure S7.

species and PICs, tree species reaching taller maximum heights had faster juvenile observed growth rates and lower adult observed mortality rates (Figure 5b; Table S3). Across angiosperm species alone, the tallest species had the largest hydraulic capacities $(r=0.55, P<0.001, N=34)$.

\section{Discussion}

\section{Relationships between Wood Density and Vascular Properties}

It is widely accepted that trade-offs must exist among wood properties related to mechanical support and hydraulic efficiency and safety, particularly involving wood density (Meinzer 2003; Chave et al. 2009). Nevertheless, although several xylem traits were significantly correlated with each other in our sample of New Zealand woody species, none was significantly correlated with wood density. Wood density was negatively correlated with lumen fraction across species, consistent with other studies (Denne, Cahalan \& Aebischer 1999; Preston, Cornwell \& DeNoyer
2006), but the correlation was weak and non-significant because podocarps maintained high lumen fractions across a range of wood densities due to their high tracheid frequencies. Among angiosperms, the relationship between lumen fraction and wood density was stronger and appeared to be constrained at an upper boundary: at a given wood density, there appeared to be a maximum attainable lumen fraction. Leptospermum scoparium was the one angiosperm outlier: this small, early successional species had the highest wood density in our data set, but also a high lumen fraction, presumably due to the dense matrix of fibers in which the xylem elements are embedded (Patel 1994). Indeed, it was a large, influential contrast involving this species that caused the relationship based on PICs to be so weak (Figure S8).

These results suggest that wood density is only partly determined by lumen fraction: the frequency and size of vessel fibers in angiosperms and the thickness of cell walls in conifers may enable wood density to vary somewhat independently of lumen fraction (Hacke et al. 2001; Preston, Cornwell \& DeNoyer 2006). Because wood density $\left(D_{\mathrm{w}}\right)$ is related to lumen fraction, $F$, as $D \mathrm{w}=D_{\mathrm{m}}(1-F)$ (Preston, Cornwell \& DeNoyer 2006), variation in the density of the matrix outside of the lumens $\left(D_{\mathrm{m}}\right)$ may play an important role in allowing woody species to escape some putative trade-offs involving wood density and conductivity. Furthermore, as vessel diameter is the chief determinant of hydraulic conductivity in angiosperm wood, wood density may be partially decoupled from conductivity.

The diameter of vessels was inversely related to vessel frequency, and this trade-off partly constrained variation in wood density and growth rate among the angiosperm tree species in our sample, as was also found by Preston, Cornwell \& DeNoyer (2006) for wood density. In other words, a limited range of wood densities and growth rates arose from these vessel diameters and frequencies, relative to what was possible given the ranges of each, had they not been negatively related. The New Zealand species covered c. $58 \%$ of the global range in wood densities (wood density range in the 39 New Zealand species: $0.4-1.1 \mathrm{~g} \mathrm{~cm}^{-3}$; global range: c. 0.1-1.5 $\mathrm{g} \mathrm{cm}^{-3}$; Chave et al. 2006). Neither the lightest woods, which would result from frequent conduits with wide diameters, nor the heaviest woods, which would result from infrequent, narrow conduits, were represented among the New Zealand species. The trade-off between diameter and frequency is linked to several interacting mechanisms (Carlquist 1975): there is both a lower limit to the density of wood required to support a tree crown without buckling (Greenhill 1881; McMahon 1973; McMahon \& Kronauer 1976), which would be approached if conduits are too wide or too frequent, and an upper limit to the density of wood due to a threshold of hydraulic resistance before inhibition of leaf expansion and photosynthesis occurs in the canopy (Brodribb et al. 2003; Koch et al. 2004; Niklas \& Spatz 2004). Aside from end-wall resistance, hydraulic conductivity of wood can be increased with longer conduits, conduits of larger diameter or with greater numbers of conduits per unit area (Carlquist 1975). All alternatives have costs: longer and wider conduits have greater risk of 
cavitation, whereas increasing conduit frequency requires more biomass in wood be used to supply the same leaf area (Castro-Diez et al. 1998; Tyree \& Ewers 1991).

\section{Relationships between Wood Properties and Demographic Rates}

Wood density was not significantly correlated with demographic rates in our data. This finding contradicts the idea that wood density is a good proxy for a tree species' position along a slow-fast rate-of-living continuum. Although strong relationships between wood density and growth and mortality rates have been observed (Smith \& Tumey 1982; Putz et al. 1983; King 1986; Chave et al. 2006; King et al. 2006b; Osunkoya et al. 2007), studies analyzing variation across larger numbers of species have found that when these correlations are statistically significant, they are often weak (Poorter et al. 2008; Chave et al. 2009). Instead, growth rate was more strongly related to xylem traits linked directly to hydraulic conductance, consistent with previous studies (Castro-Diez et al. 1998; Denne, Cahalan \& Aebischer 1999; Brodribb \& Feild 2000). The lack of a significant relationship between the demographic rates and wood densities of the New Zealand species may arise because the same wood density can be achieved by different combinations of conduit frequency, conduit diameter and wood fiber traits, and these three xylem properties each have different functional consequences for growth and mortality. Wood traits, maximum height and growth capacity are presumably functionally optimized (Niklas \& Spatz 2006). Nevertheless, we would expect those traits most closely linked to the particular functions that are under the greatest selection pressure in an environment to have the strongest relationships with demographic rates.

Our finding that mortality rates are not significantly correlated with wood traits suggests that causes of death that are independent of wood vascular properties, such as landslips and herbivory (e.g. Allen, Bellingham \& Wiser 1999; Bee, Kunstler \& Coomes 2007; Wardle 1991; Wardle \& Allen 1983; Wardle, Hayward \& Herbert 1971; Wells, Stewart \& Duncan 1998), may play a key role in New Zealand's forests. Our findings are inconsistent with the idea that denser woods, which should minimize of the hazards of falling debris, storms, wood-boring insects or pathogens (Bultman \& Southwell 1976; Putz et al. 1983; King 1986; Poorter et al. 2008), enhance tree survival in New Zealand. Similarly, our results do not support a relationship between shade tolerance and wood density (cf. King et al. 2006b), and we found no relationship between mortality rate and conduit diameter, as might be expected if species with wider vessels were at greater risk of cavitation.

\section{Maximum Height as an Axis of Differentiation among Species}

Maximum height was an important axis of differentiation among tree species in New Zealand, as in Malaysian, Australian and neotropical rain forests (Thomas 1995; Kohyama et al. 2003; King, Davies \& Supardi 2006a; Poorter et al. 2008). In contrast to Malaysian tree species (Thomas 1995), we found little evidence suggesting that taller tree species had lower density woods. We also found little evidence that the correlation between wood density and maximum height was mediated by a relationship between wood density and growth rate (Preston, Cornwell \& DeNoyer 2006).

In our data, the most conductive woods were those with fewer, wider vessels and tended to be of species reaching the tallest maximum heights, at least among angiosperms. These results suggest that tree species achieving greater heights require greater hydraulic capacity (cf. Koch et al. 2004). For angiosperms hydraulic efficiency is primarily accomplished through wider conduits, whereas for conifers it is achieved partly through increases in tracheid frequency (Sperry, Meinzer \& McCulloh 2008). Podocarps may be able to achieve such heights due to the structure of their tracheids, which are longer and have lower end-wall resistance provided by torusmargo pits, relative to angiosperms (Sperry, Hacke \& Pittermann 2006).

\section{Phylogenetic Patterns}

Our analyses with and without incorporation of evolutionary relationships were often consistent with each other. When they were not, it was frequently due to particular outlying species or related to fundamental differences in the wood anatomy of angiosperms vs. conifers, which are accounted for by including phylogenetic information in the analyses. Taxon sampling (i.e. the number or type of taxa included) can affect inferences made about correlated trait evolution among species, particularly when communities are assembled as a result of non-random processes, including dispersal (Ackerly 2000; Clark 2009). We sampled most of the common woody species in New Zealand. Nevertheless, with a few exceptions (e.g. Coprosma; Rubiaceae), they derive from diverse lineages, likely a result of the strong influence of dispersal on the New Zealand flora (McGlone 2005). Indeed, 20 families are represented among the 59 woody species in our data set. Thus, the effects of taxon sampling may be an additional factor explaining why we failed to find some trait correlations that have been documented in other studies (Putz et al. 1983; Lawton 1984; Enquist et al. 1999; King et al. 2006b; Preston, Cornwell \& DeNoyer 2006; Osunkoya et al. 2007).

\section{Conclusion}

Our analyses of interspecific variation in wood density, xylem traits and demographic rates among tree species in New Zealand found little support for the idea that wood density is a good proxy for a tree species' position along a fast-slow rate-of-living continuum. Wood density was largely decoupled from the traits' most influencing hydraulic function: vessel diameter, lumen fraction and conductivity index. Instead, the strong, negative relationship between vessel diameter and frequency that we found may limit variation in wood density and growth, but not mortal- 
ity, rates of tree species in New Zealand, and thereby constrain the realized diversity of demographic niches (sensu Condit et al. 2006). Trade-offs in function can therefore be important determinants of individual performance and have the potential to shape functional diversity and ecology of forest communities by linking selection on structure and function to population-level dynamics.

Acknowledgments - We are grateful for being able to use the permanent plot data drawn from New Zealand's National Vegetation Survey (NVS) Databank: http://nvs.landcareresearch.co.nz/. This research was supported by a Grant from the UK National Environment Research Council and the New Zealand Foundation for Research, Science and Technology (contract 9X0502). S.E.R. thanks Charlie Canham for helpful discussions of ecological modeling approaches. We thank David King for providing comments on an earlier version of this manuscript, the people and organizations who contributed to the establishment and maintenance of the NVS plots and their associated data, and Hamish Maule for tireless help in preparing the data set for use.

\section{References}

Abramoff, M. D., Magelhaes, P. J., \& Ram, S. J. (2004) Image processing with ImageJ. Biophotonics International, 11, 36-42.

Ackerly, D. D. (2000) Taxon sampling, correlated evolution, and independent contrasts. Evolution, 54, 1,480-1,492.

Allen, R. B., Bellingham, P. J., \& Wiser, S. K. (1999) Immediate damage by an earthquake to a temperate montane forest. Ecology, 80, 708-714.

Baas, P., Ewers, F. W., Davis, S. D., \& Wheeler, E. A. (2004). Evolution of xylem physiology. The Evolution of Plant Physiology (editors A. R. Hemsley \& I. Poole), pp. 273-295. Elsevier Academic Press, London, UK.

Bee, J. N., Kunstler, G., \& Coomes, D. A. (2007) Resistance and resilience of New Zealand tree species to browsing. Journal of Ecology, 95, 1,014-1,026.

Brodribb, T. J., \& Feild, T. S. (2000) Stem hydraulic supply is linked to leaf photosynthetic capacity: evidence from New Caledonian and Tasmanian rainforests. Plant, Cell \& Environment, 23, 1,381-1,388.

Brodribb, T. J., Holbrook, N. M., Edwards, E. J., \& Gutierrez, M. V. (2003) Relations between stomatal closure, leaf turgor and xylem vulnerability in eight tropical dry forest trees. Plant, Cell \& Environment, 26, 443-450.

Bultman, J. D., \& Southwell, C. R. (1976) Natural resistance of tropical American woods to terrestrial wood-destroying organisms. Biotropica, 8, 71-95.

Carlquist, S. (1975) Ecological Strategies of Xylem Evolution. University of California Press, Berkeley, California, USA.

Castro-Diez, P., Puyravaud, J. P., Cornelissen, J. H. C., \& VillarSalvador, P. (1998) Stem anatomy and relative growth rate in seedlings of a wide range of woody plant species and types. Oecologia, 116, 57-66.

Chave, J., Muller-Landau, H. C., Baker, T. R., Easdale, T. A., Steege, H. T., \& Webb, C. O. (2006) Regional and phylogenetic variation of wood density across 2,456 neotropical tree species. Ecological Applications, 16, 2,356-2,367.

Chave, J., Coomes, D., Jansen, S., Lewis, S. L., Swenson, N. G., \& Zanne, A. E. (2009) Towards a worldwide wood economics spectrum. Ecological Letters, 12, 351-366.

Clark, J. S. (2009) Beyond neutral science. TREE, 24, 8-15.
Condit, R., Ashton, P., Bunyavejchewin, S., Dattaraja, H. S., Davies, S., Esufali, S., Ewango, C., Foster, R., Gunatilleke, I. A. U. N., Gunatilleke, C. V. S., Hall, P., Harms, K. E., Hart, T., Hernandez, C., Hubbell, S., Itoh, A., Kiratiprayoon, S., Lafrankie, J., Lao, S. L. D., Makana, J., Noor, M. N. S., Kassim, A. R., Russo, S., Sukumar, R., Samper, C., Suresh, H. S., Tan, S., Thomas, S., Valencia, R., Vallejo, M., Villa, G., \& Zillio, T. (2006) Importance of demographic niches to tree diversity. Science, 313, 98-101.

Coomes, D. A., \& Allen, R. B. (2007) Effects of size, competition and altitude on tree growth. Journal of Ecology, 95, 1,084-1,097.

Davis, S. D., Sperry, J. S., \& Hacke, U. G. (1999) The relationship between xylem conduit diameter and cavitation caused by freezing. American Journal of Botany, 86, 1,367-1,372.

Denne, M. P., Cahalan, C. M., \& Aebischer, D. P. (1999) Influence of growth rate and cambial age on density of rauli (Nothofagus nervosa) in relation to vessel lumen areas and numbers. Holzforschung, 53, 199-203.

Enquist, B. J., West, G. B., Charnov, E. L., \& Brown, J. H. (1999) Allometric scaling of production and life-history variation in vascular plants. Nature, 401, 907-911.

Felsenstein, J. (1985) Phylogenies and the comparative method. American Naturalist, 125, 1-15.

Freckleton, R. P., Harvey, P. H., \& Pagel, M. (2002) Phylogenetic analysis and comparative data: a test and review of evidence. American Naturalist, 160, 712-726.

Grafen, A. (1989) The phylogenetic regression. Philosophical Transactions of the Royal Society of London, Series B: Biological Sciences, 326, 119-157.

Greenhill, A. G. (1881) Determination of the greatest height consistent with stability that a vertical pole or mast can be made, and of the greatest height to which a tree of given proportions can grow. Proceedings of the Cambridge Philosophical Society, 4,65-73.

Hacke, U. G., Sperry, J. S., Pockman, W. T., Davis, S. D., \& McCulloh, K. A. (2001) Trends in wood density and structure are linked to prevention of xylem implosion by negative pressure. Oecologia, 126, 457-461.

Holm, S. (1979) A simple sequential rejective multiple test procedure. Scandanavian Journal of Statistics, 6, 65-70.

King, D. A. (1981) Tree dimensions: maximizing the rate of height growth in dense stands. Oecologia, 51, 351-356.

King, D. A. (1986) Tree form, height growth, and susceptibility to wind damage in Acer saccharum. Ecology, 67, 980-990.

King, D. A., Davies, S. J., \& Supardi, M. N. N. (2006a) Growth and mortality are related to adult tree size in a Malaysian mixed dipterocarp forest. Forest Ecology and Management, 223, 152-158.

King, D. A., Davies, S. J., Supardi, M. N. N., \& Tan, S. (2005) Tree growth is related to light interception and wood density in two mixed dipterocarp forests of Malaysia. Functional Ecology, 19, 445-453.

King, D. A., Davies, S. J., Tan, S., \& Supardi, M. N. N. (2006b) The role of wood density and stem support costs in the growth and mortality of tropical trees. Journal of Ecology, 94, 670-680.

Koch, G. W., Sillett, S. C., Jennings, G. M., \& Davis, S. D. (2004) The limits to tree height. Nature, 428, 851-854.

Kohyama, T., Suzuki, E., Partomihardjo, T., Yamada, T., \& Kubo, T. (2003) Tree species differentiation in growth, recruitment and allometry in relation to maximum height in a Bornean mixed dipterocarp forest. Journal of Ecology, 91, 797-806.

Landcare Research (2006). New Zealand Plants Database. Avail- 
able at: http://nzflora. landcareresearch. co. nz/ (accessed November 11, 2009).

Lawton, R. O. (1984) Ecological constraints on wood density in a tropical montane rain forest. American Journal of Botany, 71, 261-267.

Maherali, H., Pocknan, W. T., \& Jackson, R. B. (2004) Adaptive variation in the vulnerability of woody plants to xylem cavitation. Ecology, 85, 2,184-2,199.

Martins, E. P., \& Hansen, T. F. (1997) Phylogenies and the comparative method: a general approach to incorporating phylogenetic information into the analysis of interspecific data. American Naturalist, 149, 646-667.

McGlone, M. S. (2005) Goodbye Gondwana. Journal of Biogeography, 32,739-740.

McMahon, T. A. (1973) Size and shape in biology. Science, 179, 1,201-1,204.

McMahon, T. A., \& Kronauer, R. E. (1976) Tree structures: deducing the principle of mechanical design. Journal of Theoretical Biology, 59, 443-466.

Meinzer, F. C. (2003) Functional convergence in plant responses to the environment. Oecologia, 134, 1-11.

Meylan, B. A., \& Butterfield, B. G. (1978) The Structure of New Zealand Woods. Science Information Division, DSIR, Wellington, New Zealand.

Muller-Landau, H. C., Condit, R. S., Chave, J., Thomas, S. C., Bohlman, S. A., Bunyavejchewin, S., Davies, S., Foster, R., Gunatilleke, S., Gunatilleke, N., Harms, K. E., Hart, T., Hubbell, S. P., Itoh, A., Kassim, A. R., LaFrankie, J. V., Lee, H. S., Losos, E., Makana, J. -R., Ohkubo, T., Sukumar, R., Sun, I. F., Supardi, M. N. N., Tan, S., Thompson, J., Valencia, R., Munoz, G. V., Wills, C., Yamakura, T., Chuyong, G., Dattaraja, H. S., Esufali, S., Hall, P., Hernandez, C., Kenfack, D., \& Kiratiprayoon, S. (2006) Testing metabolic ecology theory for allometric scaling of tree size, growth and mortality in tropical forests. Ecological Letters, 9, 575-588.

Niklas, K. J., \& Spatz, H. -C. (2004) Growth and hydraulic (not mechanical) constraints govern the scaling of tree height and mass. Proceedings of the National Academy of Sciences of the USA, 101, 15,661-15,663.

Niklas, K. J., \& Spatz, H. C. (2006) Allometric theory and the mechanical stability of large trees: proof and conjecture. American Journal of Botany, 93, 824-828.

Nogueira, E. M., Fearnside, P. M., \& Nelson, B. W. (2008) Normalization of wood density in biomass estimates of Amazon forests. Forest Ecology and Management, 256, 990-996.

Nogueira, E. M., Fearnside, P. M., Nelson, B. W., \& Franc. a, M. B. (2005) Wood density in dense forest in central Amazonia, Brazil. Forest Ecology and Management, 208, 261-286.

Osunkoya, O. O., Sheng, T. K., Mahmud, N. A., \& Damit, N. (2007) Variation in wood density, wood water content, stem growth and mortality among twenty-seven tree species in a tropical rainforest on Borneo Island. Austral Ecology, 32, 191-201.

Patel, R. (1994) Wood anatomy of dicotyledons indigenous to New Zealand 23. Myrtaceae subfamily Leptospermoideae. New Zealand Journal of Botany, 32, 95-112.

Poole, A. L., \& Adams, N. M. (1994) Trees and Shrubs of New Zealand. Manaaki Whenua Press, Lincoln, New Zealand.

Poorter, L., Wright, S. J., Paz, H., Ackerly, D. D., Condit, R., Ibarra-Manriquez, G., Harms, K. E., Licona, J. C., MartinezRamos, M., Mazer, S. J., Muller-Landau, H. C., Pena-Claros, M., Webb, C. O., \& Wright, I. J. (2008) Are functional traits good predictors of demographic rates? Evidence from five neotropical forests. Ecology, 89, 1,908-1,920.
Preston, K. A., Cornwell, W. K., \& DeNoyer, J. L. (2006) Wood density and vessel traits as distinct correlates of ecological strategy in 51 California coast range angiosperms. New Phytologist, 170, 807-818.

Putz, F. E., Coley, P. D., Lu, K., Montalvo, A., \& Aiello, A. (1983) Uprooting and snapping of trees - structural determinants and ecological consequences. Canadian Journal of Forest Research, 13, 1,011-1,020.

Russo, S. E., Wiser, S. W., \& Coomes, D. A. (2007) Growth-size scaling relationships of woody plant species differ from predictions of the Metabolic Ecology Model. Ecological Letters, 10, 889-901.

Smith, D. W., \& Tumey, P. R. (1982) Specific density and caloric value of the trunk wood of white birch, black cherry, and sugar maple and their relation to forest succession. Canadian Journal of Forest Research, 12, 186-190.

Sperry, J. S., Hacke, U. G., \& Pittermann, J. (2006) Size and function in conifer tracheids and angiosperm vessels. American Journal of Botany, 93, 1,490-1,500.

Sperry, J. S., Meinzer, F. C., \& McCulloh, K. A. (2008) Safety and efficiency conflicts in hydraulic architecture: scaling from tissues to trees. Plant, Cell \& Environment, 31, 632-645.

Stratton, L., Goldstein, G., \& Meinzer, F. C. (2000) Stem water storage capacity and efficiency of water transport: their functional significance in a Hawaiian dry forest. Plant, Cell \& Environment, 23, 99-106.

Swenson, N. G., \& Enquist, B. J. (2008) The relationship between stem and branch wood specific gravity and the ability of each measure to predict leaf area. American Journal of Botany, 95, 516-519.

The R Core Development Team (2006). A Language and Environment for Statistical Computing. R Foundation for Statistical Computing, Vienna, Austria.

Thomas, S. C. (1995) Asymptotic height as a predictor of growth and allometric characteristics in Malaysian rain forest trees. American Journal of Botany, 83, 556-566.

Tyree, M. T., Davis, S. D., \& Cochard, H. (1994) Biophysical perspectives on xylem evolution: is there a trade-off of hydraulic efficiency for vulnerability to dysfunction? International Association of Wood Anatomists Bulletin, 15, 335-360.

Tyree, M. T., \& Ewers, F. W. (1991) The hydraulic architecture of trees and other woody plants. New Phytologist, 119, 345-360.

Tyree, M. T., \& Sperry, J. S. (1989) Vulnerability of xylem to cavitation and embolism. Annual Review of Plant Physiology, 40, 19-36.

Wardle, P. (1991). Vegetation of New Zealand. Cambridge University Press, Cambridge, UK.

Wardle, J., \& Allen, R. (1983) Die-back in New Zealand Nothofagus forests. Pacific Science, 37, 397-404.

Wardle, J., Hayward, J., \& Herbert, J. (1971) Forest and scrublands of Northern Fiordland. New Zealand Journal of Forestry Science, 1, 80-115.

Wells, A., Stewart, G. H., \& Duncan, R. P. (1998) Evidence of widespread, synchronous, disturbance-initiated forest establishment in Westland, New Zealand. Journal of the Royal Society of New Zealand, 28, 333-345.

Wilson, H. D. (1994). Field Guide: Stewart Island Plants. Manuka Press, Christchurch, New Zealand.

Wiser, S. K., Bellingham, P. J., \& Burrows, L. E. (2001) Managing biodiversity information: development of New Zealand's National Vegetation Survey databank. New Zealand Journal of Ecology, 25, 1-17.

[ Supporting Information follows. ] 
Published in Functional Ecology (2010) 24: 253-262. Copyright 2010, WileyBlackwell. Used by permission.

\section{Supporting Information}

Interspecific Relationships among Tree Growth and Mortality Rates and Wood Traits

Sabrina E. Russo, ${ }^{1,2,5}$ Kerry L. Jenkins ${ }^{1}$, Susan K. Wiser ${ }^{3}$, Maria Uriarte ${ }^{4}$, Richard Duncan ${ }^{3}$, David A. Coomes ${ }^{1,3}$

${ }^{1}$ Conservation and Community Ecology Group, Department of Plant Sciences, University of Cambridge, Cambridge, UK

2 Present address: School of Biological Sciences, University of Nebraska-Lincoln, Lincoln, Nebraska, USA

${ }^{3}$ Landcare Research, Lincoln, New Zealand

${ }^{4}$ Department of Ecology and Evolution, Columbia University, New York, New York, USA

${ }^{5}$ Sabrina E. Russo: srusso2@unl.edu; phone: (1) 402-472-8387; fax: (1) 402-472-2083. 


\section{Appendix S1. Details of our approach to modelling tree growth and mortality.}

Growth model. -- We modelled individual tree growth as a function of trunk diameter, temperature, and the neighbourhood of surrounding trees. The instantaneous growth rate $(G)$ of a tree was modelled as a power function of its diameter $(D) d D / d t=\beta D^{\alpha}$ (Enquist et al. 1999; Muller-Landau et al. 2006). Because a tree's growth rate changes with its diameter, integration of this growth function gives the predicted diameter $\left(D_{t}\right)$ at time $t$ of a tree that starts with diameter $D_{0}$. We adjusted growth rates to a standard temperature ( $T_{0}$ in $\left.\mathrm{K}\right)$ based on the temperature dependence of biological processes, $\left.\mathrm{e}^{E\left(T-T_{0}\right) /(k T T}\right)_{0}$, where $E$ is the activation energy of metabolic processes $(\sim 0.65 \mathrm{eV}), k$ is the Boltzmann constant $\left(8.62 \times 10^{-5} \mathrm{eV} / \mathrm{K}\right), T$ is observed temperature in K (Gillooly et al. 2001), and $T_{0}$ is the mean temperature across all plots in the NVS data $(282 \mathrm{~K})$. After integration, the diameter at time $t$ of tree $i$ of a species is,

$D_{t i}=\left(D_{0 i}^{1-\alpha}+\beta(1-\alpha) \hat{t}_{i} e^{\frac{E\left(T_{i}-T_{0}\right)}{k T_{i} T_{0}}}\right)^{\frac{1}{1-\alpha}}+\varepsilon_{i}$

A tree's neighbourhood influences the amount of light that reaches its canopy (Weiner 1984; Canham et al. 2004; Uriarte et al. 2004), which can affect tree growth. We used a function based on the Beer-Lambert and Michealis-Menton functions to describe the effect of asymmetric competition for light (Coomes \& Allen 2007):

$$
\beta=\frac{\lambda_{1}}{\left(1+\left(\frac{\lambda_{1}}{\lambda_{2}}\right) e^{\lambda_{3} A}\right)}
$$


where $\lambda_{1}$ is the potential growth rate, $D$ is the stem diameter, and $\alpha$ defines the shape of the size effect for the target tree. $A$ is the total basal area of overtopping trees in the target tree's neighbourhood at the beginning of the time period in which growth was measured (see the main text), and the crowding effect is defined by parameters $\lambda_{2}$ and $\lambda_{3}$. Incorporating this neighbourhood function into Equation S1 gives the temperature-standardized growth-diameter scaling model, accounting for asymmetric competition:

$D_{t i}=\left(D_{0 i}^{1-\alpha}+\frac{\lambda_{1}(1-\alpha) \hat{t}_{i} e^{\frac{E\left(T_{i}-T_{0}\right)}{k T_{i} T_{0}}}}{\left(1+\left(\frac{\lambda_{1}}{\lambda_{2}}\right) e^{\frac{1}{1-\alpha}}\right)}\right)^{\lambda_{3} A_{i}}+\varepsilon_{i}$

We assumed that individual deviations from the predicted final diameter, $\varepsilon$, were lognormally distributed and depended on the length of the intercensus interval in $y, t$, which varied among trees, making the error variance scaled with time. We used the Nelder-Mead simplex search algorithm (Nelder \& Mead 1965) as implemented in the function optim in the statistical package R (The R Core Development Team 2006) to minimize the negative log likelihood function of the growth model. We fixed $\alpha$ at a range of values $<0.99$ in increments of 0.01 , and for each of these values of $\alpha$, we fit all other parameters given $\alpha$, by minimizing the negative log of the likelihood value $(-L L)$. We decreased the lower end of the range of $\alpha$ until it was clear that the $-L L$ reached a minimum. From these results, we took the MLEs for $\alpha$ and all other parameters to be the combination that had the lowest $-L L$. 
The species-specific, fitted parameter values $\left(\alpha, \beta, \lambda_{2}\right.$, and $\left.\lambda_{3}\right)$ can be used with fixed values of $D$ and $A$ to obtain the predicted growth rate of a tree with diameter $D$ in a neighbourhood with overtopping basal area $A$ at the mean temperature. We compared growth rates of juveniles at $D=40 \mathrm{~mm}$ and $A=25 \mathrm{~m}^{2} / \mathrm{ha}$ and adults at $D=200 \mathrm{~mm}$ and $A=5 \mathrm{~m}^{2} / \mathrm{ha}$ at the mean temperature across all stems in the data $\left(T_{0}=282 \mathrm{~K}\right)$. These values of $A$ are the $15^{\text {th }}$ percentiles of neighbourhood overtopping basal areas for all juvenile and adult trees in the data. These estimates of growth rate therefore represent species' predicted growth rates for juvenile and adult trees in an environment with few neighbours, that is, an environment with high availability of light.

Mortality model. -- We selected trees that had been censused $\geq 2$ times, and modelled individual mortality probability in the time interval during which a tree was observed ( $t_{0}$ to $\left.t\right)$ as a function of its diameter $(D)$ and neighbourhood $(A)$ at the beginning of that interval. We applied the approach developed by Muller-Landau et al. (2006) to account for the facts that a tree's mortality rate depends on diameter and that diameter changes in time as a tree grows, resulting in a non-constant hazard risk. If a tree's instantaneous mortality rate follows, $m(D)=$ $\delta D^{\eta}$, then this rate will change continuously as the tree grows, requiring that we integrate twice. The integrations explicitly allow the growth-diameter relationship to change with time, following $\beta D^{\alpha}$, as described above in Growth model, which causes the instantaneous hazard function $(m(D))$ also to change with respect to time, giving the cumulative hazard a tree experiences as it grows in diameter over time, $\Lambda(t)$. The survival probability during a census interval $t$ (the survival function, $S(t)$ ) of an individual that starts with diameter $D_{0}$ is thus $\mathrm{e}^{\Lambda_{(t)}}$, 
where $\Lambda(t)=\int m(D) d t=\delta D^{\eta} d t$ from $t=0$ to $t$. Substituting for $D_{t}$ and using Equation S3, we obtain $\Lambda(t)=$

$$
\begin{aligned}
& \int_{0}^{\hat{t}} \delta\left[\left[D_{0}^{1-\alpha}+\beta(1-\alpha) t e^{\frac{E\left(T-T_{0}\right)}{k T T_{0}}}\right]^{\frac{1}{1-\alpha}}\right]^{\eta} d t \\
& \int_{0}^{\hat{t}} \delta\left[D_{0}^{1-\alpha}+\beta(1-\alpha) t e^{\frac{E\left(T-T_{0}\right)}{k T T_{0}}}\right]^{\frac{\eta}{1-\alpha}} d t
\end{aligned}
$$$$
\left.\delta \frac{1}{\beta(1-\alpha)} \frac{1}{\left(\frac{\eta}{1-\alpha}+1\right)}\left[D_{0}^{1-\alpha}+\beta(1-\alpha) t e^{\frac{E\left(T-T_{0}\right)}{k T T_{0}}}\right]^{\frac{\eta}{1-\alpha}+1}\right|_{t=0} ^{t=\hat{t}}
$$$$
\left.\frac{\delta}{\beta(1-\alpha+\eta)}\left[D_{0}^{1-\alpha}+\beta(1-\alpha) t e^{\frac{E\left(T-T_{0}\right)}{k T T_{0}}}\right]^{\frac{1-\alpha+\eta}{1-\alpha}}\right|_{t=0} ^{t=\hat{t}}
$$

$$
\begin{aligned}
& \frac{\delta}{\beta(1-\alpha+\eta)}\left[\left[D_{0}^{1-\alpha}+\beta(1-\alpha) t e^{\frac{E\left(T-T_{0}\right)}{k T T_{0}}}\right]^{\frac{1-\alpha+\eta}{1-\alpha}}-\left[D_{0}^{1-\alpha}\right]^{\frac{1-\alpha+\eta}{1-\alpha}}\right] \\
& \left.\left.\frac{\delta}{\beta(1-\alpha+\eta)}\right]\left[D_{0}^{1-\alpha}+\beta(1-\alpha) t e^{\frac{E\left(T-T_{0}\right)}{k T T_{0}}}\right]^{\frac{1-\alpha+\eta}{1-\alpha}}-D_{0}^{1-\alpha+\eta}\right]
\end{aligned}
$$

Written for tree $i$ of a species, $\Lambda(t)=$

$$
\frac{\delta}{\beta(1-\alpha+\eta)}\left[\left[D_{0 i}^{1-\alpha}+\beta(1-\alpha) \hat{t}_{i} e^{\frac{E\left(T_{i}-T_{0}\right)}{k T_{i j} T_{0}}}\right]^{\frac{1-\alpha+\eta}{1-\alpha}}-D_{0 i}^{1-\alpha+\eta}\right]
$$


Equation S4 assumes that over the census interval during which mortality was estimated, a tree grows with respect to its diameter following the predicted relationship for its species using the maximum likelihood estimates for $\alpha$ and $\beta$, as fit in Russo et al. (2007).

We used a power function to model the effect of a tree's neighbourhood on its death risk, $\gamma=\frac{1}{\left(1+\lambda_{2} A^{\lambda_{1}}\right)}$

with constraints that $\lambda_{1}>0$ and $\lambda_{2}<0$ (Coomes \& Allen 2007). Thus, the cumulative hazard function $(\Lambda(t))$ for target tree $i$ of species $j$ is

$$
\frac{\delta \gamma}{\beta(1-\alpha+\eta)}\left[\left[D_{0 i}^{1-\alpha}+\beta(1-\alpha) \hat{t}_{i} e^{\frac{E\left(T_{i}-T_{0}\right)}{k T_{i} T_{0}}}\right]^{\frac{1-\alpha+\eta}{1-\alpha}}-D_{0 i}^{1-\alpha+\eta}\right]
$$

and the instantaneous mortality rate of a tree in $\mathrm{y}^{-1}$ at any time point is given by, $\gamma \delta D^{\eta}$. The species-specific, fitted values for free parameters $\left(\delta, \eta, \lambda_{1}\right.$, and $\left.\lambda_{2}\right)$ can be used in this equation to obtain the predicted instantaneous mortality rate of a tree with neighbourhood $A$ and diameter D. We compared mortality of juveniles at $D=40 \mathrm{~mm}$ and $A=80 \mathrm{~m}^{2} /$ ha and adults at $D=200$ $\mathrm{mm}$ and $A=64 \mathrm{~m}^{2} / \mathrm{ha}$ at the mean temperature across all stems in the data $\left(T_{0}=282 \mathrm{~K}\right)$. These values of $A$ represent the $85^{\text {th }}$ percentiles of neighbourhood basal areas of overtopping trees for juveniles and adults. These estimates of mortality rate therefore represent species' predicted mortality rates for juvenile and adult trees in an environment with many overtopping neighbours, that is, an environment with low availability of light.

We used maximum likelihood methods to estimate species-specific parameters. Because not all trees in our data died, the data are censored. The likelihood $\left(L_{i}\right)$ for tree $i$ that died by 
time $t_{i}$ (measured in y) is $L_{i}=1-S\left(t_{i}\right)$ where $S\left(t_{i}\right)$ is the survival function, or the probability of surviving to time $t_{i}$. If the tree is still alive at time $t_{i}$, then all that is known is that the lifetime exceeds $t_{i}$, and the probability of this is $L_{i}=S\left(t_{i}\right)$. If $d_{i}$ is an indicator variable that is 1 if the tree died by time $t_{i}$ and 0 otherwise, we can write these contributions to the $\log$ likelihood $(\log L)$ for $n$ trees of a species,

$\log L=\sum_{i=1}^{n}\left(1-d_{i}\right) \log \left[S\left(t_{i}\right)\right]+d_{i}\left(1-\log \left[S\left(t_{i}\right)\right]\right)$

where $S\left(t_{i}\right)=e^{\Lambda} \Lambda_{(t i)}$. To fit parameters, we minimized the negative of this log likelihood function using the Nelder-Mead simplex search algorithm (Nelder \& Mead 1965) as implemented in the function optim in the statistical package R (The R Core Development Team 2006). Parameters $\alpha$ and $\beta$ were fixed at their MLEs. We fixed $\eta$ at a range of values $<0.99$ in increments of 0.01 , and for each of these values of $\eta$, we fit all other parameters given $\eta$, by minimizing the negative log likelihood value. We decreased the lower end of the range of $\eta$ until it was clear that the negative log likelihood value reached a minimum. From these results, we took the MLEs for $\eta$ and all other parameters to be the combination that had the lowest negative log likelihood value. 


\section{Appendix S2. Details of phylogenetic independent contrast analyses for cases with} polytomies.

There were two genera in our phylogenetic tree with polytomies: Coprosma and Olearia (Fig. S1). There were no more than two species represented in Coprosma and Olearia in the data sets for the xylem traits, wood density, juvenile predicted growth and mortality rates, and adult observed and predicted growth and mortality rates. Thus, the phylogeny used in any phylogenetic independent contrast analysis involving these traits did not require resolution of polytomies.

Analyses involving maximum height and juvenile observed growth and mortality rates for both Coprosma and Olearia required resolution of polytomies. The number of species in each genus in each of these two comparisons involved in a polytomy were:

1) Maximum height \& juvenile observed growth:

Coprosma -8 species and Olearia -3 species

2) Maximum height \& juvenile observed mortality:

$$
\text { Coprosma }-9 \text { species and Olearia }-3 \text { species }
$$

Given that the phylogenetic tree for species not in Coprosma or Olearia does not change, the number of possible bifurcating trees for $n$ species is $(2 n-3) ! /\left(2^{n-2}(n-2) !\right)($ Cavalli-Svorza and Edwards 1967). For resolving the polytomies in the two cases above, there would be a total of $6,081,075$ possible trees. We therefore generated a set of 1000 random resolutions for each of the cases above, and examined the distribution of the correlation statistics (Fig. S2). We reported the mean Pearson's correlation coefficient and maximum probability from these 1000 randomizations. 


\section{Appendix S3. Details of the phylogenetic generalized least-squares analyses}

We examined how wood vascular properties that were found to be significantly negatively correlated (conduit diameter and frequency, Table 1, Fig. 1 in main text) jointly affected wood density of angiosperms using a statistical model. A trade-off between vessel diameter and frequency implies that certain combinations of these traits are not favoured in nature, which could limit the possible variation in wood density. To examine this possibility, we fit a statistical model to the relationship of wood density with vessel diameter and frequency:

$$
\log \left(D_{w}\right)=a \log (N)+b \log (D)+c
$$

where $a, b$, and $c$ were fitted parameters. A strong relationship between predictors can result in multicollinearity, which does not reduce the predictive power of the overall model, but can reduce the interpretability of individual parameter estimates. We therefore restricted interpretation to the overall model fit, and took a significant fit to imply that the trade-off between vessel diameter and frequency constrained variation in wood density.

This model was fit using two regression methods, ordinary least squares (OLS) and phylogenetic generalized least squares (PGLS) (Martins \& Hansen 1997; Freckleton et al. 2002). That is, we constructed phylogenetic covariance matrices specifying two models of evolution: The first model assumed that model errors were uncorrelated with phylogeny. We fitted this model using OLS regression, which is equivalent to using PGLS and specifying a phylogenetic covariance matrix with the off-diagonal elements set to zero and the diagonals set to a constant. The second model, based on PGLS, specified a Brownian-motion process of evolution 
(Felsenstein 1985) by calculating the off-diagonal elements of the phylogenetic covariance matrix as the length of the shared branches between species from the root of the tree to the last common ancestor (Garland \& Ives 2000), scaled by the branch length from the root to the tip of the tree. Following Grafen (1989), we estimated branch lengths by setting the height of each node equal to the number of daughter taxa minus one. The model of trait variation is specified as a fixed effect in the regression model, and the influence of phylogeny is accounted for by incorporating a matrix of expected phylogenetic variances and covariances into calculation of the regression parameters.

We also estimated a multiplier of the off-diagonal elements of the phylogenetic covariance matrix $(\lambda)$ (Freckleton et al. 2002). $\lambda$ measures the strength of phylogenetic signal in the data, having accounted for the adaptive hypothesis specified in the regression model (Hansen \& Orzack 2005). It can range between 0 and 1: values of $\lambda$ close to 0 imply low phylogenetic signal ( $\lambda=0$ is equivalent to the OLS model), and values of $\lambda$ close to 1 imply strong phylogenetic signal. We fitted PGLS models by including the phylogenetic covariance matrices in generalized least-squares regression models, with $\lambda$ estimated using maximum likelihood, using the statistical package R version 2.0.1, as in Duncan et al. (2007).

We compared the fits of the OLS and PGLS models to the data using Akaike's information criterion (AIC) (Hilborn \& Mangel 1997). In all cases, the AIC was always lower for the OLS model, and estimates of $\lambda$ were close to zero. Therefore, only results from OLS models are presented in the main text. 


\section{Literature Cited for Appendices S1 - S3}

Canham C.D., LePage P.T. \& Coates K.D. (2004). A neighborhood analysis of canopy tree competition: effects of shading versus crowding. Can. J. For. Res. 34, 778-787.

Cavalli-Sforza, L. L. and A. W. F. Edwards. (1967). Phylogenetic analysis: models and estimation procedures. Evolution 32, 550-570.

Coomes, D.A. \& Allen, R.B. (2007). Effects of size, competition and altitude on tree growth. Ecol. Lett., 95, 1084-1097.

Duncan R.P., Forsyth D.M. \& Hone J. (2007). Testing the metabolic theory of ecology: allometric scaling exponents in mammals. Ecology, 88, 324-333.

Enquist, B.J., West, G.B., Charnov, E.L. \& Brown, J.H. (1999). Allometric scaling of production and life-history variation in vascular plants. Nature, 401, 907-911.

Felsenstein, J. (1985). Phylogenies and the comparative method. Am. Nat., 125, 1-15.

Freckleton, R.P., Harvey, P.H. \& Pagel, M. (2002). Phylogenetic analysis and comparative data: A test and review of evidence. Am Nat, 160, 712-726.

Garland T. \& Ives A.R. (2000). Using the past to predict the present: Confidence intervals for regression equations in phylogenetic comparative methods. Am. Nat., 155, 346-364.

Gillooly, J.F., Brown, J.H., West, G.B., Savage, V.M. \& Charnov, E.L. (2001). Effects of size and temperature on metabolic rate. Science, 293, 2248-2251.

Grafen A. (1989). The phylogenetic regression. Phil. Tran. Roy. Soc. B, 326, 199-157. 
Hansen T.F. \& Orzack S.H. (2005). Assessing current adaptation and phylogenetic inertia as explanations of trait evolution: The need for controlled comparisons. Evolution, 59, 20632072.

Hilborn R. \& Mangel M. (1997). The Ecological Detective. Princeton University Press, Princeton, N.J.

Martins, E.P. \& Hansen, T.F. (1997). Phylogenies and the comparative method: A general approach to incorporating phylogenetic information into the analysis of interspecific data. Am. Nat., 149, 646-667.

Muller-Landau, H.C., Condit, R.S., Chave, J., Thomas, S.C., Bohlman, S.A., Bunyavejchewin, S., Davies, S., Foster, R., Gunatilleke, S., Gunatilleke, N., Harms, K.E., Hart, T., Hubbell, S.P., Itoh, A., Kassim, A.R., LaFrankie, J.V., Lee, H.S., Losos, E., Makana, J.-R., Ohkubo, T., Sukumar, R., Sun, I.-F., Supardi M.N.N., Tan, S., Thompson, J., Valencia, R., Munoz, G.V., Wills, C., Yamakura, T., Chuyong, G., Dattaraja, H.S., Esufali, S., Hall, P., Hernandez, C., Kenfack, D. \& Kiratiprayoon, S. (2006). Testing metabolic ecology theory for allometric scaling of tree size, growth and mortality in tropical forests. Ecol. Lett., 9, 575-588.

Nelder J.A. \& Mead R. (1965). A simplex algorithm for function minimization. Computer Journal, 7, 308-313.

The R Core Development Team (2006). A language and environment for statistical computing. In. R Foundation for Statistical Computing Vienna, Austria. 
Russo, S.E., Wiser, S.W. \& Coomes, D.A. (2007). Growth-size scaling relationships of woody plant species differ from predictions of the Metabolic Ecology Model. Ecol. Lett., 10, 889901.

Uriarte M., Condit R., Canham C.D. \& Hubbell S.P. (2004). A spatially explicit model of sapling growth in a tropical forest: does the identity of neighbours matter? J Ecology, 92, 348-360.

Weiner J. (1984). Neighborhood interference amongst Pinus rigida individuals. J. Ecol., 72, 183195. 
Table S1. Wood traits and growth and mortality rates of woody species of New Zealand.

\section{Species}

Archeria traversii

Aristotelia serrata

Beilschmiedia tawa

Brachyglottis buchananii

Brachyglottis repanda

Carpodetus serratus

Coprosma areolata

Coprosma australis

Coprosma ciliata

Coprosma foetidissima

Coprosma linariifolia

Coprosma parviflora

Coprosma pseudociliata

Coprosma tenuifolia

Cyathodes juniperina

Dacrydium bidwillii

Dacrydium cupressinum

Dracophyllum longifolium

Dracophyllum traversii

Eleaocarpus dentatus

Eleaocarpus hookerianus

Fuchsia excorticata

Griselinia littoralis

Halocarpus biformis

Hedycarya arborea

Hoheria glabrata

Knightia excelsa

Kunzea ericoides

Laurelia novae zelandiae

$\begin{array}{lcccc}\begin{array}{l}\text { Family } \\ \text { Epacridaceae }\end{array} & \begin{array}{c}\text { Growth } \\ \text { form }\end{array} & \begin{array}{c}\text { Maximum } \\ \text { height }\end{array} & \begin{array}{c}\text { Wood } \\ \text { density }\end{array} & \begin{array}{c}\text { Frequency } \\ \text { of vessels }\end{array} \\ \text { Elaeocarpaceae } & \text { ST } & 5 & 0.74 & 420 \\ \text { Lauraceae } & \text { CT } & 30 & 0.52 & 80 \\ \text { Asteraceae } & \text { SH } & 3 & 0.70 & 25 \\ \text { Asteraceae } & \text { ST } & 7 & - & - \\ \text { Rubiaceae } & \text { ST } & 10 & 0.65 & 76 \\ \text { Rubiaceae } & \text { SH } & 5 & - & 151 \\ \text { Rubiaceae } & \text { ST } & 7 & 0.81 & - \\ \text { Rubiaceae } & \text { SH } & 3 & - & 109 \\ \text { Rubiaceae } & \text { SH } & 4 & 0.72 & - \\ \text { Rubiaceae } & \text { ST } & 8 & - & - \\ \text { Rubiaceae } & \text { SH } & 5 & - & - \\ \text { Rubiaceae } & \text { SH } & 4 & - & - \\ \text { Rubiaceae } & \text { SH } & 5 & - & - \\ \text { Epacridaceae } & \text { SH } & 5 & - & - \\ \text { Podocarpaceae } & \text { SH } & 4 & - & - \\ \text { Podocarpaceae } & \text { CT } & 50 & 0.59 & - \\ \text { Epacridaceae } & \text { SH } & 3 & 0.52 & 488 \\ \text { Epacridaceae } & \text { ST } & 10 & - & - \\ \text { Elaeocarpaceae } & \text { CT } & 20 & 0.52 & 96 \\ \text { Elaeocarpaceae } & \text { ST } & 14 & 0.52 & 171 \\ \text { Onagraceae } & \text { ST } & 13 & 0.70 & 55 \\ \text { Cornaceae } & \text { CT } & 17 & 0.63 & 190 \\ \text { Podocarpaceae } & \text { ST } & 10 & 0.80 & - \\ \text { Monimiaceae } & \text { CT } & 15 & 0.62 & 168 \\ \text { Malvaceae } & \text { ST } & 10 & - & - \\ \text { Proteaceae } & \text { CT } & 30 & 0.59 & 97 \\ \text { Myrtaceae } & \text { CT } & 16 & 0.77 & 69 \\ \text { Monimiaceae } & \text { CT } & 30 & - & -\end{array}$

\begin{tabular}{|c|}
\hline $\begin{array}{c}\text { Frequency } \\
\text { of early } \\
\text { vessels }\end{array}$ \\
\hline 204 \\
\hline- \\
\hline - \\
\hline - \\
\hline- \\
\hline- \\
\hline- \\
\hline 64 \\
\hline- \\
\hline 59 \\
\hline- \\
\hline- \\
\hline- \\
\hline- \\
\hline- \\
\hline- \\
\hline- \\
\hline- \\
\hline- \\
\hline- \\
\hline- \\
\hline - \\
\hline- \\
\hline- \\
\hline- \\
\hline $\begin{array}{l}- \\
-\end{array}$ \\
\hline- \\
\hline \\
\hline
\end{tabular}

\section{Frequency \\ of late}

vessels tracheids

248

041.00

$-$

-

$-$

6538.00 
Table S1, continued.

\begin{tabular}{|c|c|c|c|c|c|c|c|}
\hline Species & $\begin{array}{c}\text { Mean } \\
\text { diameter of } \\
\text { conduits }\end{array}$ & $\begin{array}{c}\text { Mean } \\
\text { diameter of } \\
\text { early conduits }\end{array}$ & $\begin{array}{c}\text { Mean } \\
\text { diameter of } \\
\text { late conduits }\end{array}$ & $\begin{array}{l}\text { Conductivity } \\
\text { index }\end{array}$ & $\begin{array}{l}\text { Lumen } \\
\text { fraction }\end{array}$ & $\begin{array}{l}\text { Mean observed } \\
\text { juvenile growth } \\
\text { rate (SD) }\end{array}$ & $\begin{array}{l}\text { Mean observed } \\
\text { adult growth } \\
\text { rate (SD) }\end{array}$ \\
\hline Archeria traversii & 13.40 & 11.46 & 14.99 & 13.53 & 0.06 & $0.20(0.59)$ & - \\
\hline Aristotelia serrata & 41.05 & - & - & 227.17 & 0.11 & - & - \\
\hline Beilschmiedia tawa & 62.58 & - & - & 383.43 & 0.08 & $1.01(1.25)$ & $2.35(2.40)$ \\
\hline Brachyglottis buchananii & - & - & - & - & - & $0.69(1.42)$ & - \\
\hline Brachyglottis repanda & 30.99 & - & - & 70.10 & 0.06 & $0.38(0.83)$ & - \\
\hline Carpodetus serratus & 24.09 & - & - & 50.85 & 0.07 & $0.80(1.29)$ & $1.12(1.32)$ \\
\hline Coprosma areolata & - & - & - & - & - & $1.93(1.44)$ & - \\
\hline Coprosma australis & 24.60 & 23.38 & 25.61 & 39.90 & 0.05 & $0.75(1.08)$ & - \\
\hline Coprosma ciliata & - & - & - & - & - & $0.49(0.70)$ & - \\
\hline Coprosma foetidissima & 19.81 & 20.42 & 19.48 & 24.93 & 0.05 & $0.44(0.65)$ & - \\
\hline Coprosma linariifolia & - & - & - & - & - & $0.66(0.79)$ & - \\
\hline Coprosma parviflora & - & - & - & - & - & $0.25(0.60)$ & - \\
\hline Coprosma pseudociliata & - & - & - & - & - & $0.16(0.47)$ & - \\
\hline Coprosma tenuifolia & - & - & - & - & - & $0.72(0.80)$ & - \\
\hline Cyathodes juniperina & - & - & - & - & - & $0.28(0.41)$ & - \\
\hline Dacrydium bidwillii & - & - & - & - & - & $0.36(0.43)$ & - \\
\hline Dacrydium cupressinum & 13.31 & - & - & 64.06 & 0.28 & $0.71(0.98)$ & $1.04(1.09)$ \\
\hline Dracophyllum longifolium & 10.86 & - & - & 6.79 & 0.05 & $0.33(0.49)$ & - \\
\hline Dracophyllum traversii & - & - & - & - & - & $0.34(0.44)$ & - \\
\hline Eleaocarpus dentatus & 36.91 & - & - & 178.18 & 0.10 & - & - \\
\hline Eleaocarpus hookerianus & 23.71 & - & - & 54.04 & 0.08 & $0.37(0.63)$ & - \\
\hline Fuchsia excorticata & 35.62 & - & - & 88.54 & 0.05 & $0.91(1.48)$ & $1.57(1.48)$ \\
\hline Griselinia littoralis & 21.43 & - & - & 40.07 & 0.07 & $0.72(1.13)$ & $1.43(1.92)$ \\
\hline Halocarpus biformis & 6.97 & - & - & 15.43 & 0.25 & $0.66(4.52)$ & - \\
\hline Hedycarya arborea & 26.99 & - & - & 89.15 & 0.10 & $1.21(1.36)$ & - \\
\hline Hoheria glabrata & - & - & - & - & - & $0.86(1.49)$ & - \\
\hline Knightia excelsa & 40.24 & - & - & 254.33 & 0.12 & $1.31(1.44)$ & - \\
\hline Kunzea ericoides & 32.44 & - & - & 76.41 & 0.06 & $0.72(1.04)$ & $1.49(1.71)$ \\
\hline Laurelia novae zelandiae & - & - & - & - & - & - & - \\
\hline
\end{tabular}


Table S1, continued.

\section{Species}

Archeria traversii

Aristotelia serrata

Beilschmiedia tawa

Brachyglottis buchananii

Brachyglottis repanda

Carpodetus serratus

Coprosma areolata

Coprosma australis

Coprosma ciliata

Coprosma foetidissima

Coprosma linariifolia

Coprosma parviflora

Coprosma pseudociliata

Coprosma tenuifolia

Cyathodes juniperina

Dacrydium bidwillii

Dacrydium cupressinum

Dracophyllum longifolium

Dracophyllum traversii

Eleaocarpus dentatus

Eleaocarpus hookerianus

Fuchsia excorticata

Griselinia littoralis

Halocarpus biformis

Hedycarya arborea

Hoheria glabrata

Knightia excelsa

Kunzea ericoides

Laurelia novae zelandiae

$\begin{array}{cc}\begin{array}{c}\text { Observed } \\ \text { juvenile } \\ \text { mortality rate } \\ 0.0083\end{array} & \begin{array}{c}\text { Observed } \\ \text { adult } \\ \text { mortality rate }\end{array} \\ 0.1022 & - \\ 0.0097 & - \\ 0.0565 & 0.0106 \\ 0.1332 & - \\ 0.0229 & - \\ 0.0516 & 0.0190 \\ 0.0507 & - \\ 0.0266 & - \\ 0.0428 & - \\ 0.0163 & - \\ 0.0325 & - \\ 0.0346 & - \\ 0.0392 & - \\ 0.0140 & - \\ 0.0096 & - \\ 0.0057 & 0.0016 \\ 0.0153 & - \\ 0.0083 & - \\ - & - \\ 0.0187 & - \\ 0.0451 & 0.0426 \\ 0.0167 & 0.0119 \\ 0.0088 & - \\ 0.0177 & - \\ 0.0405 & 0.0205 \\ 0.0071 & - \\ 0.0227 & 0.0097 \\ 0.0167 & - \\ & \end{array}$

Predicted juvenile highlight growth rate
0.29
0.67
-
0.53
$-$
0.34
0.66
$-$
$-$
$-$
0.84
$-$
$-$
$-$
0.53
0.82
0.38

Predicted adult high-light juvenile low-light growth rate

-
-
-
-
-
-
-
-
-
-
-
-
-
-
-
-
0.99
-
-
-
-
-
-
-
-
-
-
-
-

Predicted adult low-light mortality rate mortality rate

0.0137

0.0154

0.1550

0.0715

-

0.0496

0.0491<smiles>C1=CCCCC1</smiles>

$-$

0.0088

0.0226

-

$-$

0.0326

0.0219

0.1180
0.0028

0.0094 
Table S1, continued.

$\begin{array}{llcccc}\text { Species } & \begin{array}{c}\text { Family } \\ \text { Lepidothamnus intermedius }\end{array} & \begin{array}{c}\text { Growth } \\ \text { form }\end{array} & \begin{array}{c}\text { Maximum } \\ \text { height }\end{array} & \begin{array}{c}\text { Wood } \\ \text { density }\end{array} & \begin{array}{c}\text { Frequency } \\ \text { of vessels }\end{array} \\ \text { Leptospermum scoparium } & \text { Myrtaceae } & \text { ST } & 9 & - & - \\ \text { Leucopogon fasciculatus } & \text { ST } & 8 & 1.03 & 95 \\ \text { Litsea calicaris } & \text { Lauraceae } & \text { SH } & 5 & 0.73 & 182 \\ \text { Melicytus ramiflorus } & \text { Violaceae } & \text { ST } & 15 & - & - \\ \text { Metrosideros umbellata } & \text { Myrtaceae } & \text { CT } & 10 & 0.59 & 130 \\ \text { Myrsine australis } & \text { Myrsinaceae } & \text { ST } & 7 & 0.96 & 11 \\ \text { Myrsine divaricata } & \text { Myrsinaceae } & \text { SH } & 4 & 0.75 & 162 \\ \text { Myrsine salicina } & \text { Myrsi-ceae } & \text { ST } & 10 & 0.65 & 255 \\ \text { Pseudopanax colensoi } & \text { Araliaceae } & \text { ST } & 7 & - & 60 \\ \text { Neomyrtus pedunculata } & \text { Myrtaceae } & \text { SH } & 5 & 0.80 & - \\ \text { Nothofagus fusca } & \text { Fagaceae } & \text { CT } & 35 & 0.62 & 138 \\ \text { Nothofagus menziesii } & \text { Fagaceae } & \text { CT } & 30 & 0.67 & 349 \\ \text { Nothofagus solandri } & \text { Fagaceae } & \text { CT } & 27 & 0.61 & 204 \\ \text { Olearia avicenniifolia } & \text { Asteraceae } & \text { ST } & 7 & 0.74 & 261 \\ \text { Olearia colensoi } & \text { Asteraceae } & \text { SH } & 5 & - & - \\ \text { Olearia ilicifolia } & \text { Asteraceae } & \text { ST } & 7 & 0.93 & 58 \\ \text { Phyllocladus alpinus } & \text { Podocarpaceae } & \text { ST } & 8 & 0.76 & - \\ \text { Podocarpus hallii } & \text { Podocarpaceae } & \text { CT } & 20 & 0.58 & - \\ \text { Prumnopitys ferruginea } & \text { Podocarpaceae } & \text { CT } & 35 & - & - \\ \text { Prumnopytis taxifolia } & \text { Podocarpaceae } & \text { CT } & 40 & 0.62 & - \\ \text { Pseudowintera axillaris } & \text { Winteraceae } & \text { ST } & 8 & - & - \\ \text { Pseudowintera colorata } & \text { Winteraceae } & \text { ST } & 10 & - & - \\ \text { Pseudopanax crassifolius } & \text { Araliaceae } & \text { ST } & 13 & 0.76 & 124 \\ \text { Pseudopanax linearis } & \text { Araliaceae } & \text { ST } & 6 & 0.81 & 220 \\ \text { Pseudopanax simplex } & \text { Araliaceae } & \text { ST } & 8 & 0.54 & 452 \\ \text { Quintinia acutifolia } & \text { Escaloniaceae } & \text { ST } & 13 & 0.63 & 297 \\ \text { Quintinia serrata } & \text { Escaloniaceae } & \text { ST } & 12 & 0.49 & 416 \\ \text { Shefflera digitata } & \text { Araliaceae } & \text { ST } & 12 & - & - \\ \text { Weinmannia racemosa } & \text { Cunoniaceae } & \text { CT } & 26 & 0.58 & 373\end{array}$

$\begin{array}{ccc}\begin{array}{c}\text { Frequency } \\ \text { of early } \\ \text { vessels }\end{array} & \begin{array}{c}\text { Frequency } \\ \text { of late } \\ \text { vessels }\end{array} & \begin{array}{c}\text { No. } \\ \text { tracheids }\end{array} \\ - & - & - \\ - & - & - \\ - & - & - \\ - & - & - \\ - & - & - \\ - & - & - \\ - & - & - \\ - & - & - \\ - & - & - \\ - & - & - \\ 182 & 200 & - \\ 77 & 56 & - \\ 130 & 211 & - \\ 73 & 94 & - \\ - & - & - \\ - & - & - \\ 11 & 50 & - \\ - & - & 1814.00 \\ - & - & 4216.00 \\ - & - & - \\ - & - & 2298.00 \\ - & - & - \\ - & - & - \\ - & - & - \\ - & - & - \\ - & - & - \\ - & - & - \\ - & - & - \\ - & - & - \\ - & - & \end{array}$


Table S1, continued.

\begin{tabular}{|c|c|c|c|c|c|c|c|}
\hline Species & $\begin{array}{c}\text { Mean } \\
\text { diameter of } \\
\text { conduits }\end{array}$ & $\begin{array}{c}\text { Mean } \\
\text { diameter of } \\
\text { early conduits }\end{array}$ & $\begin{array}{c}\text { Mean } \\
\text { diameter of } \\
\text { late conduits }\end{array}$ & $\begin{array}{l}\text { Conductivity } \\
\text { index }\end{array}$ & $\begin{array}{l}\text { Lumen } \\
\text { fraction }\end{array}$ & $\begin{array}{l}\text { Mean observed } \\
\text { juvenile growth } \\
\text { rate (SD) }\end{array}$ & $\begin{array}{l}\text { Mean observed } \\
\text { adult growth } \\
\text { rate (SD) }\end{array}$ \\
\hline Lepidothamnus intermedius & - & - & - & - & - & $0.32(0.37)$ & - \\
\hline Leptospermum scoparium & 47.94 & - & - & 501.78 & 0.17 & $0.93(1.16)$ & - \\
\hline Leucopogon fasciculatus & 20.20 & - & - & 30.30 & 0.06 & $0.30(0.49)$ & - \\
\hline Litsea calicaris & - & - & - & - & - & $1.27(1.55)$ & - \\
\hline Melicytus ramiflorus & 30.52 & - & - & 112.79 & 0.10 & $0.73(1.01)$ & $1.13(1.81)$ \\
\hline Metrosideros umbellata & 62.34 & - & - & 166.13 & 0.03 & $0.74(2.50)$ & $1.01(1.99)$ \\
\hline Myrsine australis & 24.57 & - & - & 59.04 & 0.08 & $0.66(0.75)$ & - \\
\hline Myrsine divaricata & 16.86 & - & - & 20.60 & 0.06 & $0.32(0.53)$ & - \\
\hline Myrsine salicina & 28.52 & - & - & 39.70 & 0.04 & $0.53(0.85)$ & - \\
\hline Pseudopanax colensoi & - & - & - & - & - & $0.46(0.91)$ & - \\
\hline Neomyrtus pedunculata & 16.44 & 18.59 & 14.48 & 27.02 & 0.08 & $0.21(0.54)$ & - \\
\hline Nothofagus fusca & 35.38 & 40.08 & 28.92 & 216.25 & 0.14 & $1.08(1.27)$ & $2.26(2.50)$ \\
\hline Nothofagus menziesii & 12.02 & 23.45 & 4.98 & 7.29 & 0.04 & $0.57(1.12)$ & $1.44(1.95)$ \\
\hline Nothofagus solandri & 27.06 & 32.50 & 22.84 & 109.42 & 0.12 & $0.85(1.18)$ & $1.56(1.60)$ \\
\hline Olearia avicenniifolia & 14.77 & - & - & 12.42 & 0.04 & $0.29(1.21)$ & - \\
\hline Olearia colensoi & - & - & - & - & - & $0.49(0.65)$ & - \\
\hline Olearia ilicifolia & 32.60 & 48.04 & 29.20 & 65.49 & 0.05 & $1.10(1.13)$ & - \\
\hline Phyllocladus alpinus & 17.79 & - & - & 181.69 & 0.45 & $0.44(0.61)$ & - \\
\hline Podocarpus hallii & 9.93 & - & - & 40.99 & 0.33 & $0.27(0.61)$ & $0.38(1.06)$ \\
\hline Prumnopitys ferruginea & - & - & - & - & - & $0.88(2.01)$ & $1.07(1.26)$ \\
\hline Prumnopytis taxifolia & 8.83 & - & - & 13.97 & 0.14 & - & - \\
\hline Pseudowintera axillaris & - & - & - & - & - & $0.60(0.69)$ & - \\
\hline Pseudowintera colorata & - & - & - & - & - & $0.59(0.83)$ & - \\
\hline Pseudopanax crassifolius & 30.58 & - & - & 108.44 & 0.09 & $0.69(0.77)$ & - \\
\hline Pseudopanax linearis & 16.20 & - & - & 15.15 & 0.05 & $0.33(0.45)$ & - \\
\hline Pseudopanax simplex & 14.54 & - & - & 20.20 & 0.08 & $0.63(0.71)$ & - \\
\hline Quintinia acutifolia & 29.30 & - & - & 218.89 & 0.20 & $1.13(0.92)$ & $1.14(1.49)$ \\
\hline Quintinia serrata & 32.35 & - & - & 455.61 & 0.34 & - & - \\
\hline Shefflera digitata & - & - & - & - & - & $0.88(1.47)$ & - \\
\hline Weinmannia racemosa & 26.33 & - & - & 179.27 & 0.20 & $0.68(1.22)$ & $1.27(1.97)$ \\
\hline
\end{tabular}


Table S1, continued.

\section{Species}

Lepidothamnus intermedius

Leptospermum scoparium

Leucopogon fasciculatus

Litsea calicaris

Melicytus ramiflorus

Metrosideros umbellata

Myrsine australis

Myrsine divaricata

Myrsine salicina

Pseudopanax colensoi

Neomyrtus pedunculata

Nothofagus fusca

Nothofagus menziesii

Nothofagus solandri

Olearia avicenniifolia

Olearia colensoi

Olearia ilicifolia

Phyllocladus alpinus

Podocarpus hallii

Prumnopitys ferruginea

Prumnopytis taxifolia

Pseudowintera axillaris

Pseudowintera colorata

Pseudopanax crassifolius

Pseudopanax linearis

Pseudopanax simplex

Quintinia acutifolia

Quintinia serrata

Shefflera digitata

Weinmannia racemosa

$\begin{array}{cc}\begin{array}{c}\text { Observed } \\ \text { juvenile } \\ \text { mortality rate } \\ 0.0016\end{array} & \begin{array}{c}\text { Observed } \\ \text { adult } \\ \text { mortality rate }\end{array} \\ 0.0204 & - \\ 0.0182 & - \\ 0.0154 & - \\ 0.0191 & - \\ 0.0111 & 0.0148 \\ 0.0139 & -0049 \\ 0.0126 & - \\ 0.0136 & - \\ 0.0538 & - \\ 0.0120 & - \\ 0.0230 & 0.0077 \\ 0.0134 & 0.0043 \\ 0.0227 & 0.0128 \\ 0.0595 & - \\ 0.0201 & - \\ 0.0141 & - \\ 0.0198 & - \\ 0.0089 & 0.0121 \\ 0.0047 & 0.0023 \\ - & - \\ 0.0111 & - \\ 0.0168 & - \\ 0.0218 & - \\ 0.0247 & - \\ 0.0268 & - \\ 0.0181 & 0.0280 \\ - & - \\ 0.0554 & - \\ 0.0100 & 0.0070 \\ & \end{array}$

Predicted juvenile high-

\section{light growth rate}

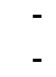

$-$

0.54

1.21

0.40

0.25

0.59

$-$

0.81

0.66

0.98

$-$

0.97

0.26

0.54

0.62

0.58

0.56

0.58

0.41

\section{Predicted adult high-light growth rate}
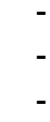

-

0.43

-

$-$

-

2.95

1.13

1.70

-

$-$

0.43

-

$-$

-

$-$

$-$

$-$

-

0.96
Predicted

juvenile low-light mortality rate

0.0479

0.0555

0.0233

0.0102

0.0149

0.0149

-

0.0378

0.0211

0.0648

-

0.0248

0.0103

0.0023

0.0093

0.0134

0.0239

0.0276

0.0238

-

0.0140
Predicted adult low-light mortality rate

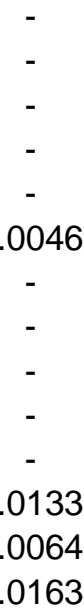

0.0064
0.0163

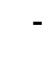

0.0056

-

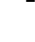

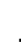

-

$-$

-

.0036 
Russo et al.

Page 20 of 36

Notes:

Growth forms are: SH, shrub; CT, canopy tree; ST, small tree. Standard deviations (SD) are in parentheses. See Methods in the main text for units. A dash indicates no data were available. 
Table S2. Values of Akaike's information criterion (AIC) for ordinary least squares (OLS) and phylogenetic generalized least squares (PGLS) fits to the model, $\log (R)=a \log (N)+b \log (D)+c$, where $R$ is the dependent variable (either species' wood density or observed mean growth or mortality rate), $N$ is vessel frequency, $D$ is vessel diameter, and $a, b$, and $c$ are fitted parameters.

\section{AIC}

Model

OLS

PGLS

Wood properties: Vessel diameter and number of vessels

Dependent variable: Wood density

Dependent variable: Mean growth rate

Dependent variable: Mean mortality rate

72.069

73.859 
Table S3. Relationships between wood properties and adult growth and mortality rates of New Zealand woody species. The Pearson correlation coefficient $(\rho)$ and corresponding $P$-value and sample size $(N$; number of species) are presented for the relationships between species' (1) mean growth rate $(\mathrm{mm} / \mathrm{y}),(2)$ predicted growth rate $(\mathrm{mm} / \mathrm{yr})$ for a 200-mm diameter tree in a highlight environment (neighbourhood basal area of $5 \mathrm{~m}^{2} / \mathrm{ha}$ ), (3) mean instantaneous mortality rate $\left(\mathrm{y}^{-1}\right)$, and (4) predicted instantaneous mortality rate for a $200 \mathrm{~mm}$ diameter tree in a shaded environment (neighbourhood basal area of $64 \mathrm{~m} / \mathrm{ha}$ ) with 6 wood properties: wood density $\left(\mathrm{g} / \mathrm{cm}^{3}\right)$, number of conduits (vessels or tracheids) per $\mathrm{mm}^{2}$, , mean diameter of conduits $(\mu \mathrm{m})$, conductivity index, lumen fraction $\left(\mathrm{mm}^{2} / \mathrm{mm}^{2}\right)$, and maximum tree height $(\mathrm{m})$. Estimation was based on stems $\geq 200 \mathrm{~mm}$ in diameter. Correlations are estimated based on log-transformed species values or phylogenetically independent contrasts. Values in bold are statistically significant after correction for multiple comparisons. See Demographic data and analytical methods and Appendix S1 for the details of demographic rate estimation. 


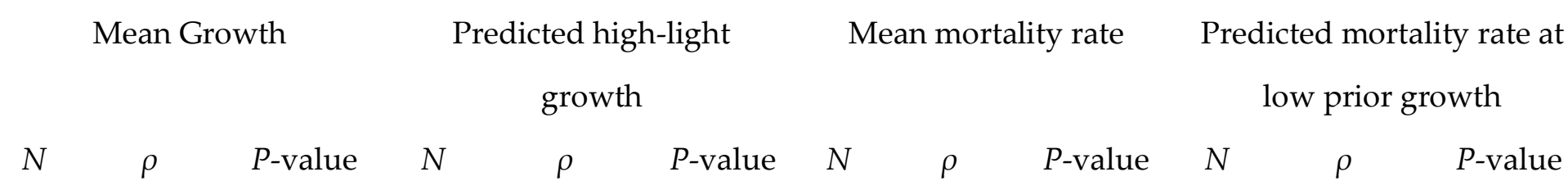

Correlations based on species' trait values

$\begin{array}{lcccccccccccc}\text { Wood density } & 14 & 0.17 & 0.559 & 7 & -0.40 & 0.370 & 14 & -0.05 & 0.852 & 8 & -0.10 & 0.814 \\ \text { Vessel freq. } & 12 & -0.11 & 0.741 & 5 & 0.59 & 0.294 & 12 & 0.07 & 0.819 & 6 & 0.19 & 0.721 \\ \text { Conduit diam. } & 14 & 0.58 & 0.029 & 7 & 0.13 & 0.787 & 14 & 0.28 & 0.336 & 8 & 0.23 & 0.588 \\ \text { Cond. Index } & 14 & 0.33 & 0.253 & 7 & 0.18 & 0.704 & 14 & 0.22 & 0.451 & 8 & 0.07 & 0.867 \\ \text { Lumen fraction } & 14 & -0.43 & 0.126 & 7 & 0.05 & 0.921 & 14 & -0.12 & 0.687 & 8 & -0.23 & 0.581 \\ \text { Maximum height } & 15 & 0.17 & 0.545 & 7 & 0.59 & 0.161 & 15 & \mathbf{- 0 . 8 0} & <0.001 & 8 & -0.22 & 0.600\end{array}$

Correlations based on phylogenetically independent contrasts

$\begin{array}{lccccccccccrrr}\text { Wood density } & 13 & -0.07 & 0.809 & 6 & -0.32 & 0.537 & 13 & -0.65 & 0.017 & 7 & -0.51 & 0.243 \\ \text { Vessel freq. } & 11 & -0.09 & 0.798 & 4 & -0.31 & 0.686 & 11 & 0.27 & 0.419 & 5 & 0.08 & 0.894 \\ \text { Conduit diam. } & 13 & 0.50 & 0.083 & 6 & 0.66 & 0.150 & 13 & -0.13 & 0.664 & 7 & 0.29 & 0.527 \\ \text { Cond. Index } & 13 & 0.45 & 0.123 & 6 & 0.68 & 0.137 & 13 & 0.06 & 0.851 & 7 & 0.41 & 0.361 \\ \text { Lumen fraction } & 13 & 0.21 & 0.499 & 6 & 0.52 & 0.290 & 13 & 0.33 & 0.269 & 7 & 0.49 & 0.264 \\ \text { Maximum height } & 14 & 0.67 & 0.009 & 6 & 0.78 & 0.069 & 14 & \mathbf{- 0 . 8 0} & <\mathbf{0 . 0 0 1} & 7 & -0.27 & 0.564\end{array}$


Figure S1. The phylogenetic hypothesis for woody plant species of New Zealand used in phylogenetic comparative analyses, drawn with unitary branch lengths and polytomies. This tree is based on an unpublished phylogeny provided by S.J. Wagstaff, A. Wilton, M. Cochrane, and G. Barker (http://plantphylogeny.landcareresearch.co.nz/WebFroms/Home.aspx), which is based in part on sequences of the gene coding for the large subunit of ribulose-1,5-bisphosphate carboxylase (rbcL), and augmented with relationships derived from the literature listed below. For independent contrast analyses using the R-function ape, polytomies were randomly resolved (see Methods in main text for more details).

Additional published literature used in phylogeny construction:

Cross, E.W., Quinn, C.J., Wagstaff, S.J. 2002. Molecular evidence for the polyphyly of Olearia (Astereae: Asteraceae). Plant Systematics and Evolution 235: 99-120.

Mitchell, A.D., Wagstaff, S.J. 1997. Phylogenetic relationships of Pseudopanax species (Araliaceae) inferred from parsimony analysis of rDNA sequence data and morphology. Plant Systematics and Evolution 208: 121-138. 
Russo et al.

Page 25 of 36

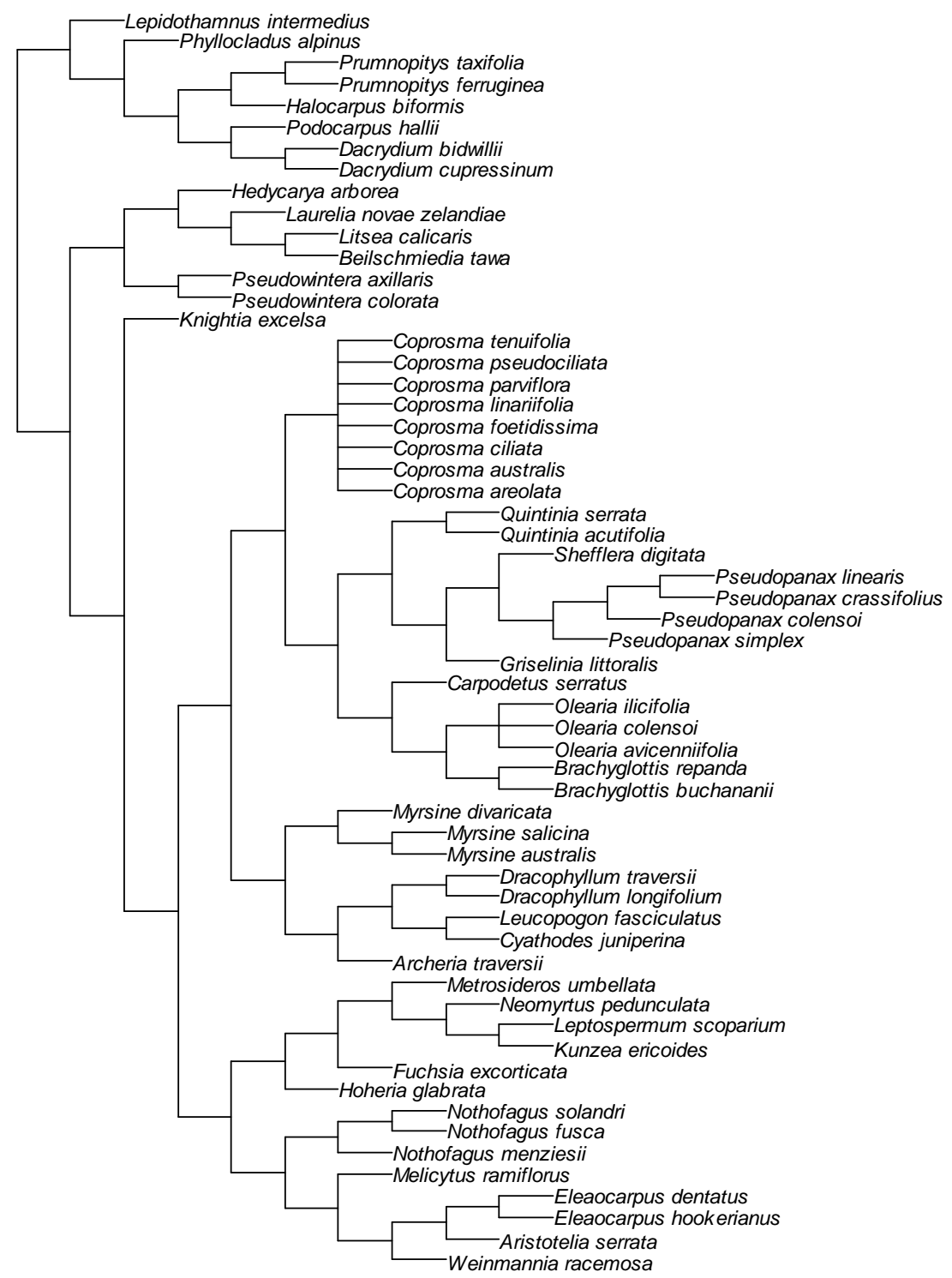


Figure S2. Distributions of the Pearson correlation coefficient and probability value for the relationship between phylogenetic independent contrasts calculated from juvenile observed growth $(\mathrm{A}$ and $\mathrm{B})$ and mortality $(\mathrm{C}$ and $\mathrm{D})$ rates with maximum height of New Zealand's tree species, based on 1000 random resolutions of polytomies in the phylogenetic tree (Figure S1; Appendix S2).
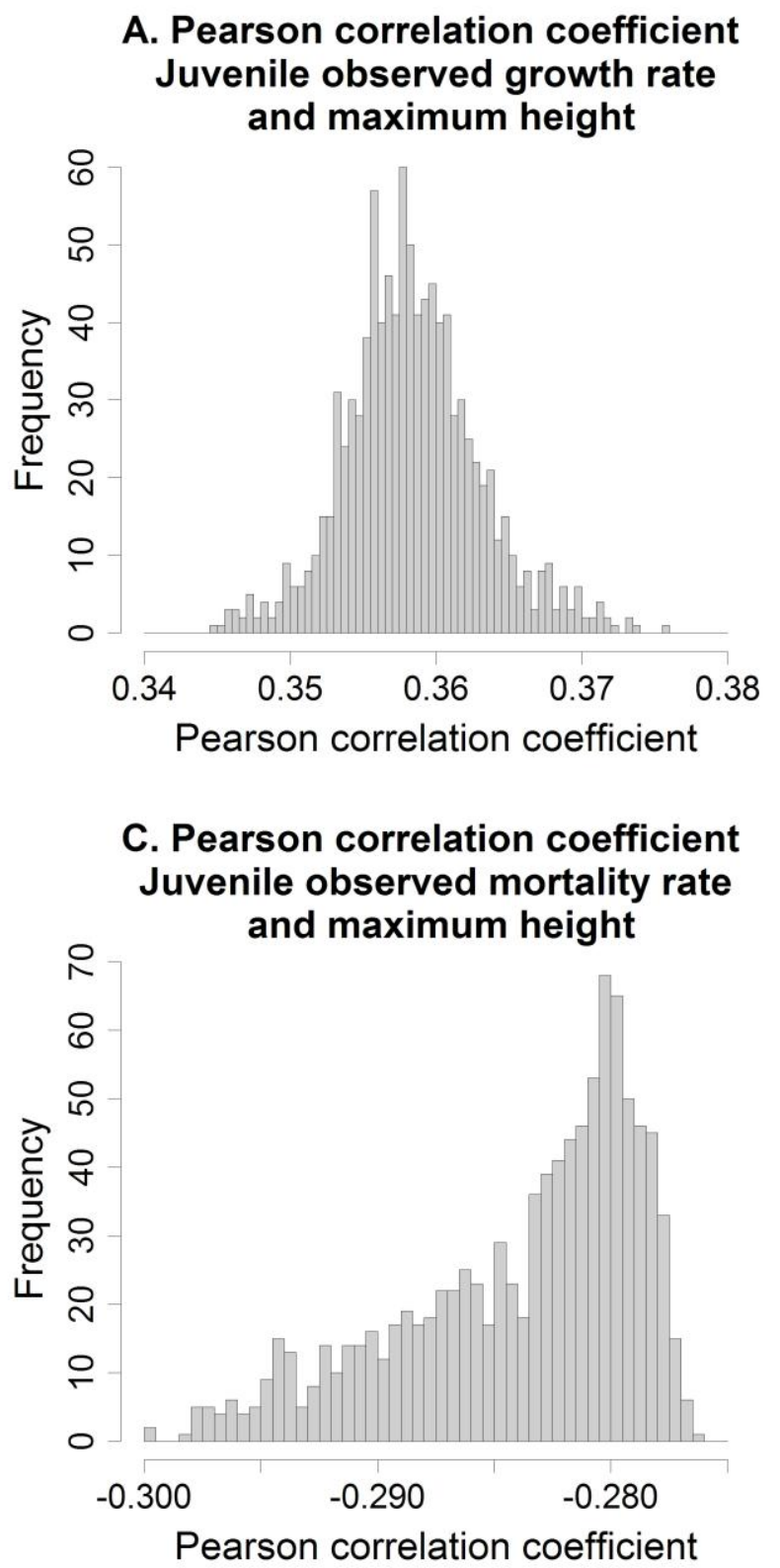

B. Probability value Juvenile observed growth rate and maximum height
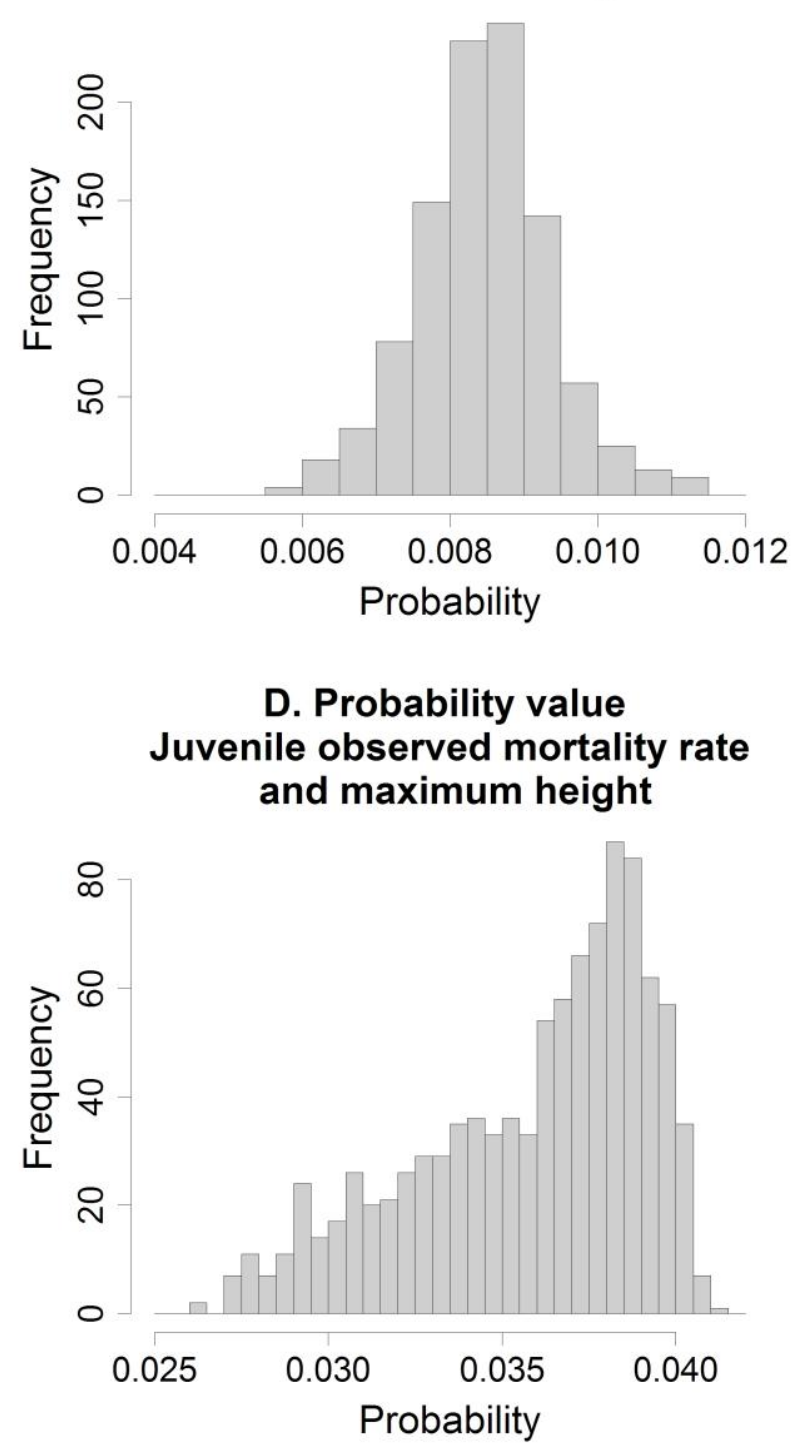
Figure S3. The relationships between five wood properties of New Zealand tree species: wood density $\left(\mathrm{g} / \mathrm{cm}^{3}\right)$, number of conduits per $\mathrm{mm}^{2}$, mean diameter of conduits $(\mu \mathrm{m})$, conductivity index $\left(\mu \mathrm{m}^{2}\right)$, and lumen fraction $\left(\mathrm{mm}^{2} / \mathrm{mm}^{2}\right)$, plotted on log-log scales. The asterisk indicates relationships with significant correlations after correction for multiple comparisons. Symbols: black triangles, canopy trees; gray squares, understory trees; black circles, shrubs; filled symbols, angiosperms; open symbols, conifers.
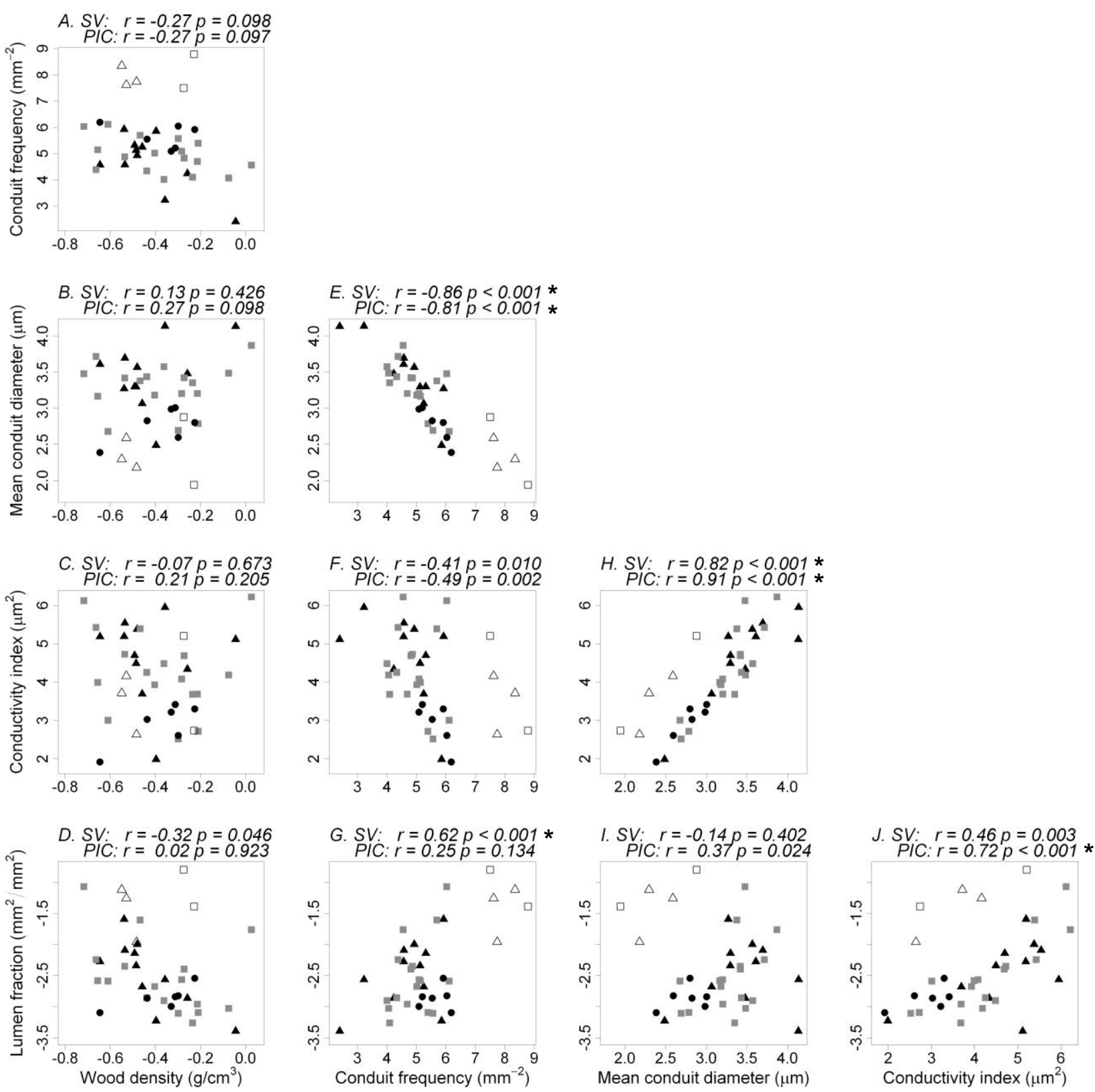
Figure S4. Relationships between observed growth and mortality rates and those predicted by a neighbourhood crowding model. See Appendix S1 for modelling details.
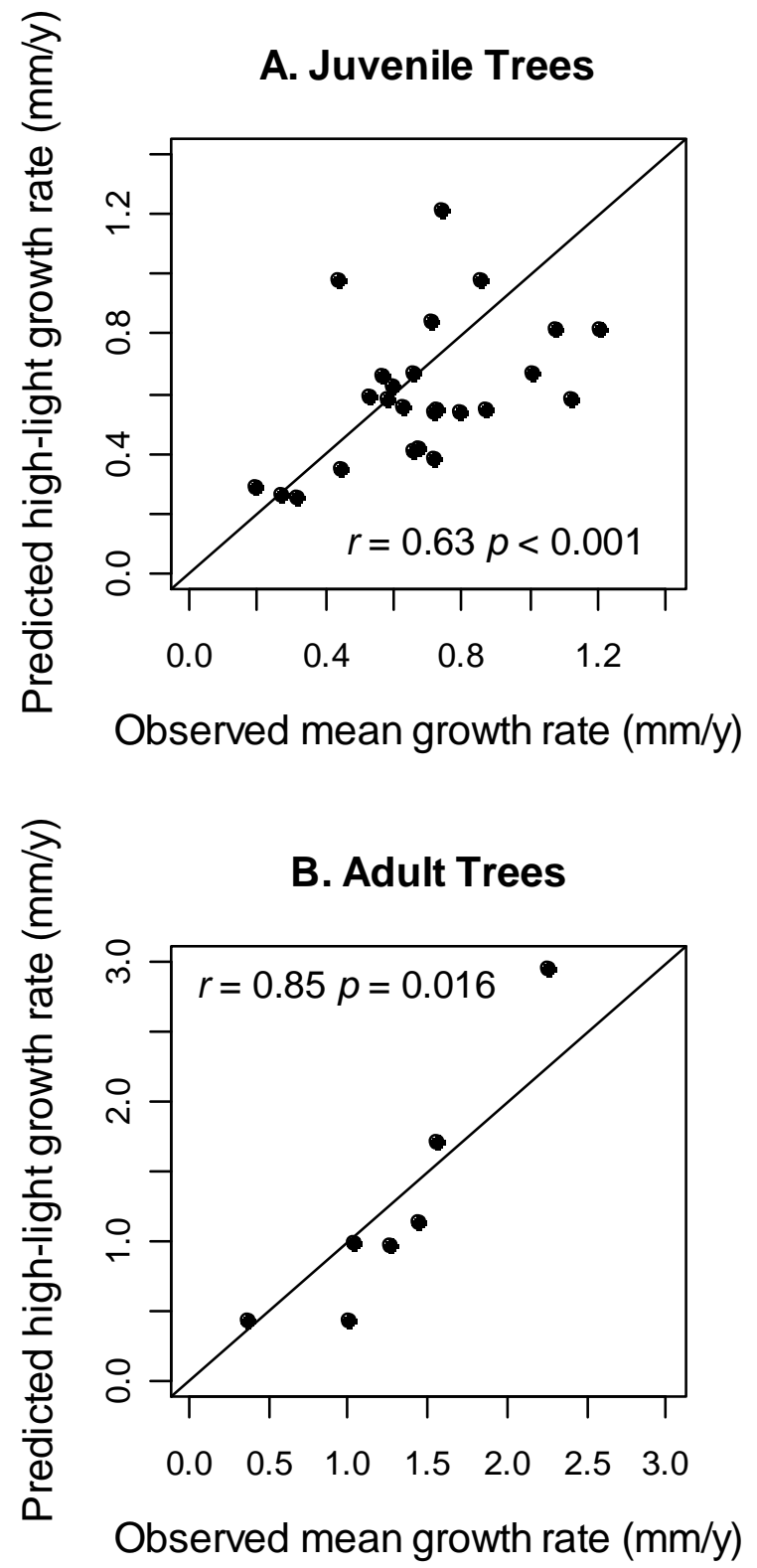
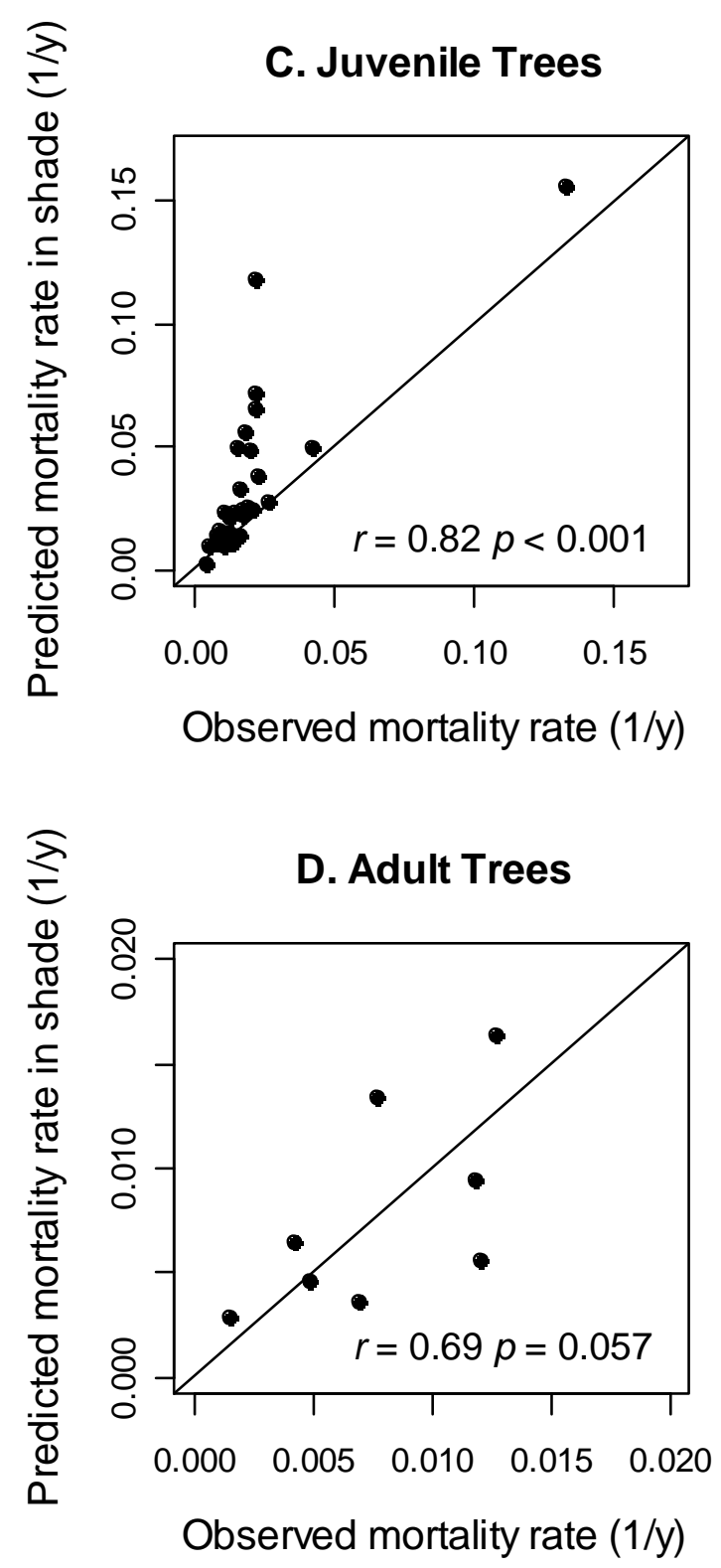
Figure S5. The relationships of five wood properties with juvenile growth rates of tree species of New Zealand. Wood properties are wood density $\left(\mathrm{g} / \mathrm{cm}^{3}\right)$, number of vessels per $\mathrm{mm}^{2}$, mean conduit diameter $(\mu \mathrm{m})$, conductivity index $\left(\mu \mathrm{m}^{2}\right)$, and lumen fraction $\left(\mathrm{mm}^{2} / \mathrm{mm}^{2}\right)$. Growth rates for each species are observed mean diameter growth rates (a - e) and predicted diameter growth rate for a 40-mm diameter tree in a high-light environment (neighbourhood overtopping basal area of $25 \mathrm{~m}^{2} / \mathrm{ha}$ ) (f - j). Estimation was based on stems 30-200 $\mathrm{mm}$ in diameter; see Demographic data and analytical methods for details. Symbols: black triangles, canopy trees; gray squares, understory trees; black circles, shrubs; filled symbols, angiosperms; open symbols, conifers. The asterisk indicates relationships with significant correlations after correction for multiple comparisons for species' values (SV) and phylogenetically independent contrasts (PIC). Axes are plotted on log scales. 

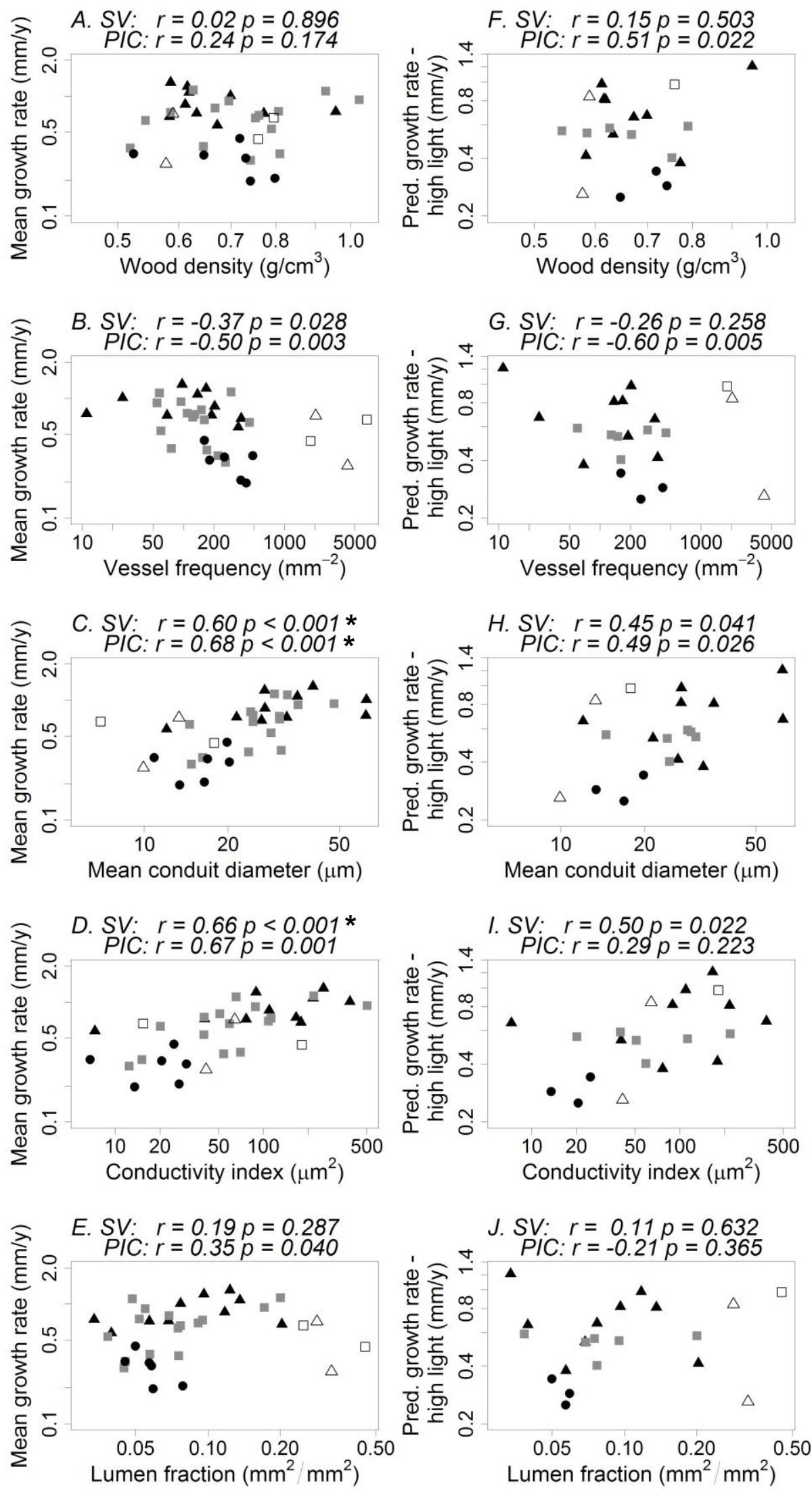
Figure S6. The relationships of five wood properties with juvenile mortality rates of New Zealand tree species. Wood properties are wood density $\left(\mathrm{g} / \mathrm{cm}^{3}\right)$, number of vessels per $\mathrm{mm}^{2}$, mean conduit diameter $(\mu \mathrm{m})$, conductivity index $\left(\mu \mathrm{m}^{2}\right)$, and lumen fraction $\left(\mathrm{mm}^{2} / \mathrm{mm}^{2}\right)$. Mortality rates for each species are mean instantaneous mortality rates (a - e) and predicted instantaneous mortality rate of each species for a 40-mm diameter tree in a shaded environment (neighbourhood overtopping basal area of $80 \mathrm{~m}^{2} / \mathrm{ha}$ ) $(\mathrm{f}-\mathrm{j})$. Estimation was based on stems 30 $200 \mathrm{~mm}$ in diameter; see Demographic data and analytical methods for details. Symbols: black triangles, canopy trees; gray squares, understory trees; black circles, shrubs; filled symbols, angiosperms; open symbols, conifers. The asterisk indicates relationships with significant correlations after correction for multiple comparisons for species' values (SV) and phylogenetically independent contrasts (PIC). Axes are plotted on log scales. 

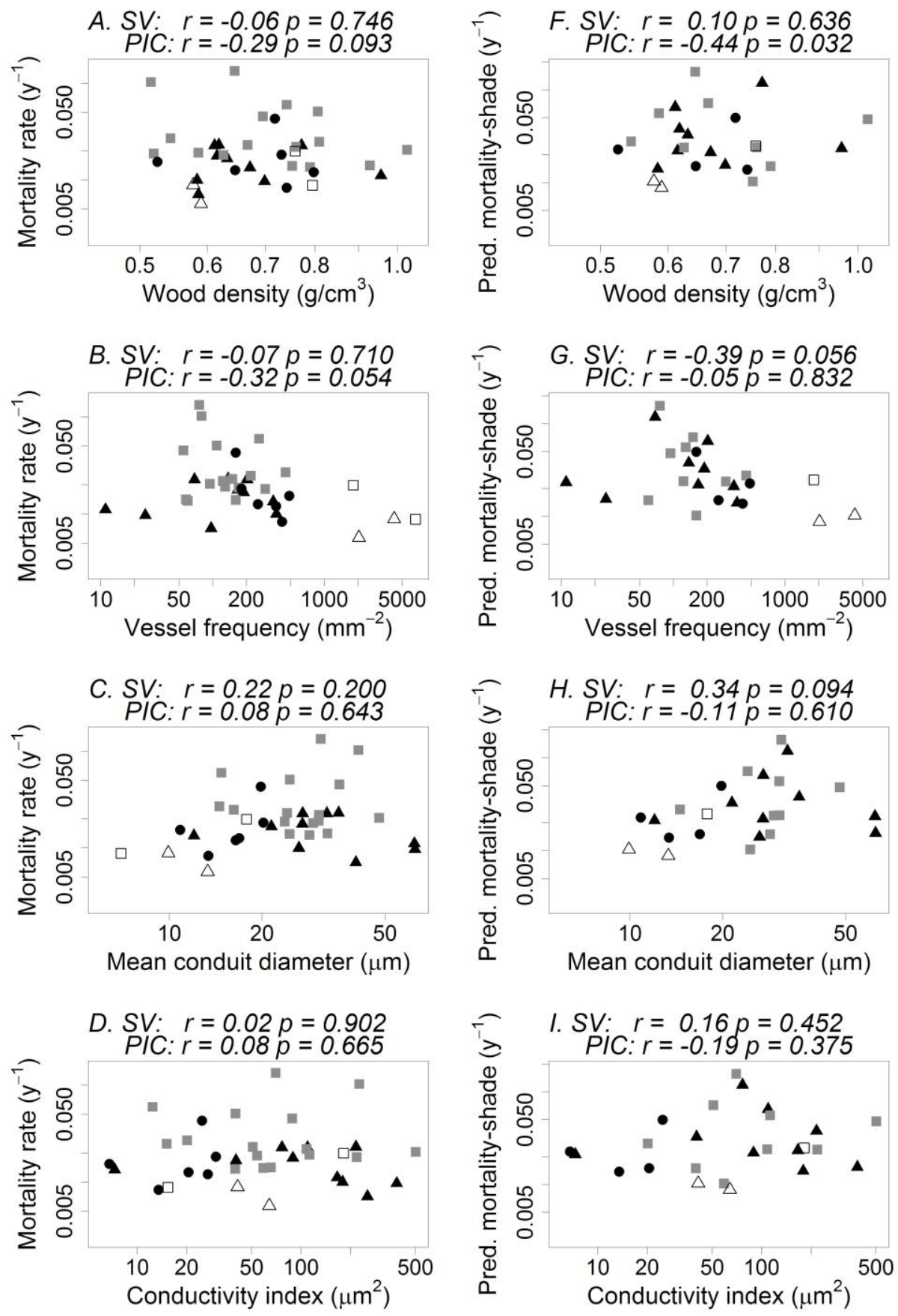

E. SV: $r=-0.30 p=0.076$

PIC: $r=0.03 p=0.849$
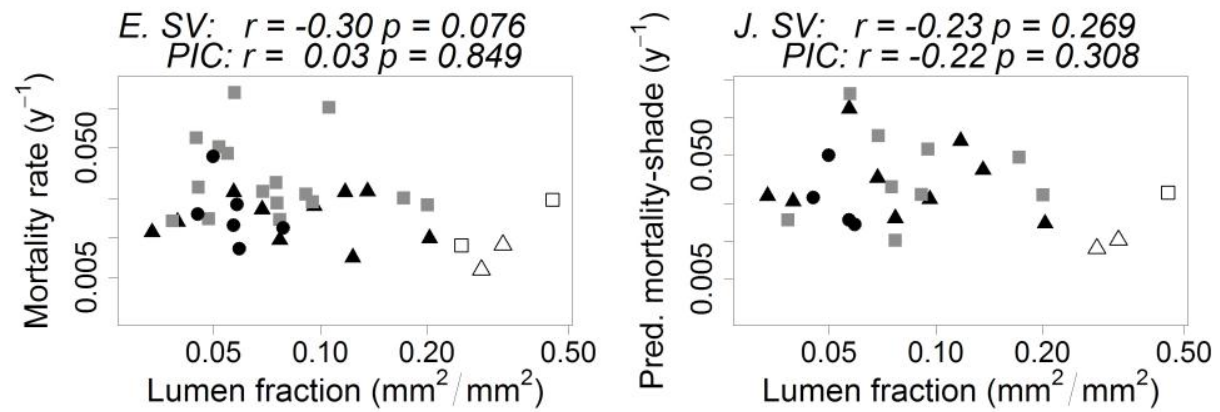
Figure S7. The relationships of maximum tree height $(\mathrm{m})$ with five wood properties (a-e) and juvenile growth and mortality rates (f - i) of New Zealand tree species. Wood properties are wood density $\left(\mathrm{g} / \mathrm{cm}^{3}\right)$, number of vessels per $\mathrm{mm}^{2}$, mean conduit diameter $(\mu \mathrm{m})$, conductivity index $\left(\mu \mathrm{m}^{2}\right)$, and lumen fraction $\left(\mathrm{mm}^{2} / \mathrm{mm}^{2}\right)$. Demographic rates for each species are: observed mean diameter growth rates, predicted diameter growth rate for a $40-\mathrm{mm}$ diameter tree in a high-light environment (neighbourhood overtopping basal area of $25 \mathrm{~m}^{2} / \mathrm{ha}$ ), observed mean instantaneous mortality rates, and predicted instantaneous mortality rate of each species for a 40-mm diameter tree in a shaded environment (neighbourhood overtopping basal area of 80 $\left.\mathrm{m}^{2} / \mathrm{ha}\right)(\mathrm{f}-\mathrm{j})$. Estimation was based on stems 30-200 mm in diameter; see Demographic data and analytical methods for details. The asterisk indicates relationships with significant correlations after correction for multiple comparisons for species' values (SV) and phylogenetically independent contrasts (PIC). Axes are plotted on log scales. Note that in (F) and (I), the mean correlation coefficient and maximum probability for PICs are based on 1000 random resolutions of the phylogeny (Appendix S2, Fig. S2). 

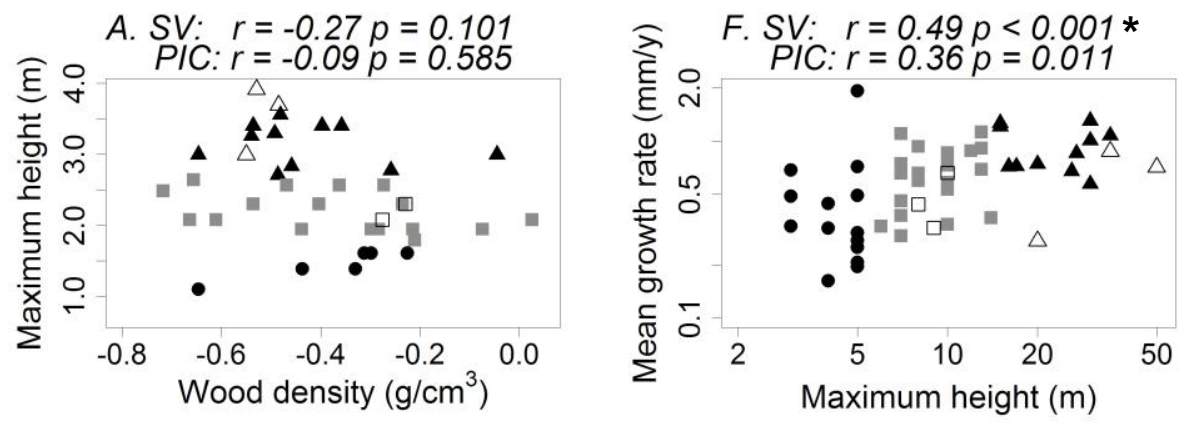

B. SV: $r=0.05 p=0.757$
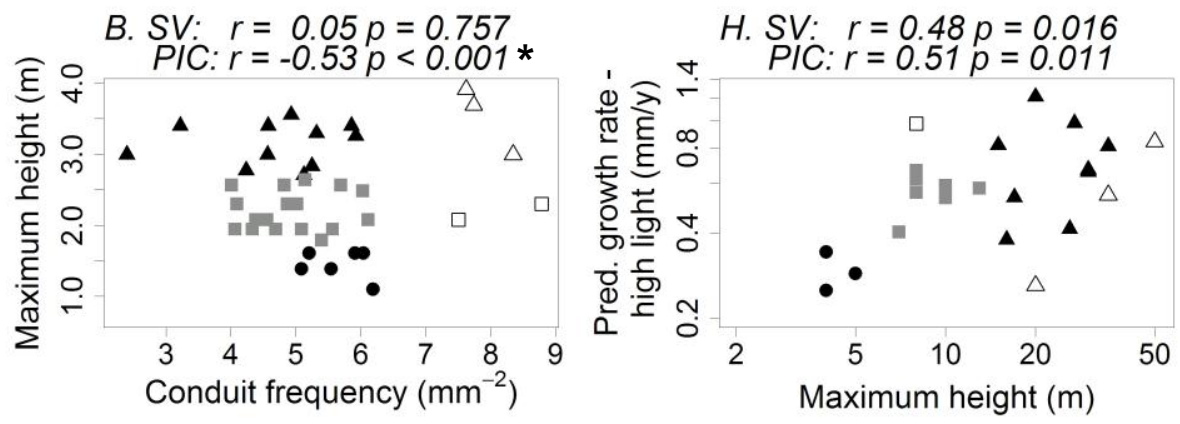

C. SV: $r=0.18 p=0.271$
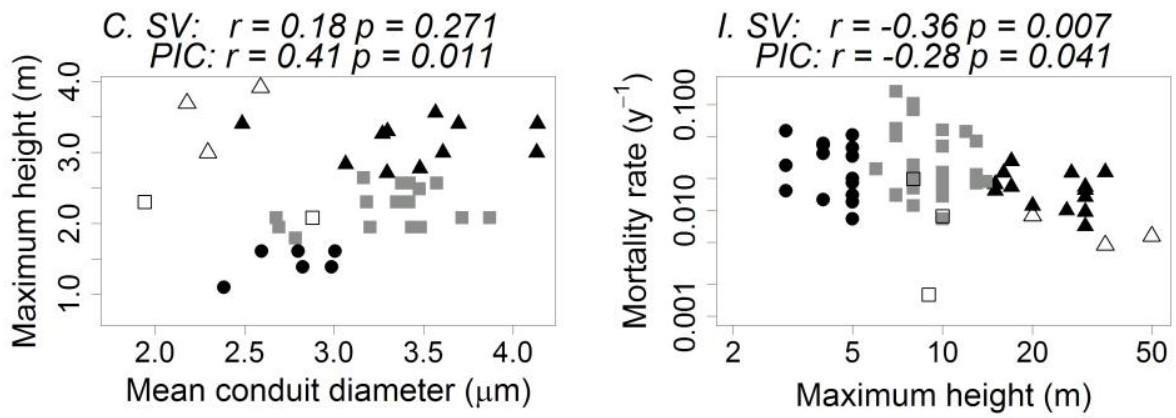

D. SV: $r=0.38 p=0.016$
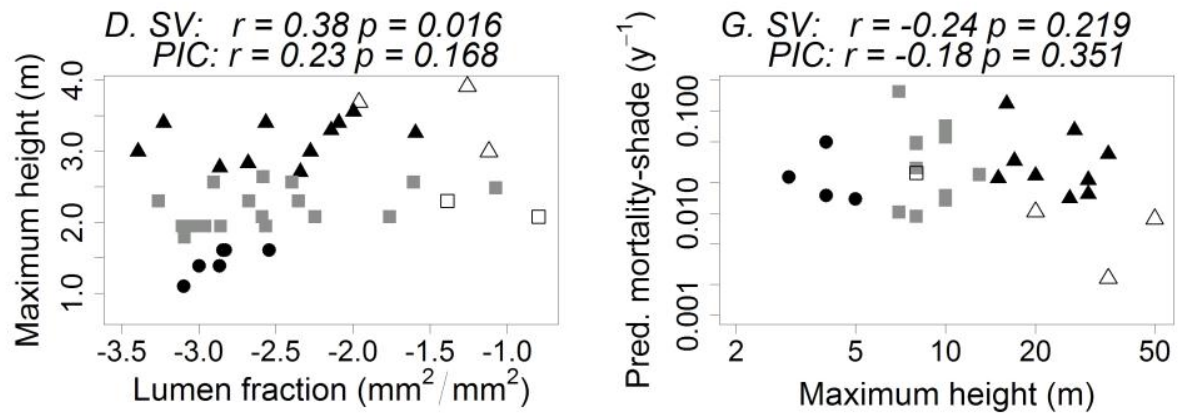

E. SV: $r=0.38 p=0.018$

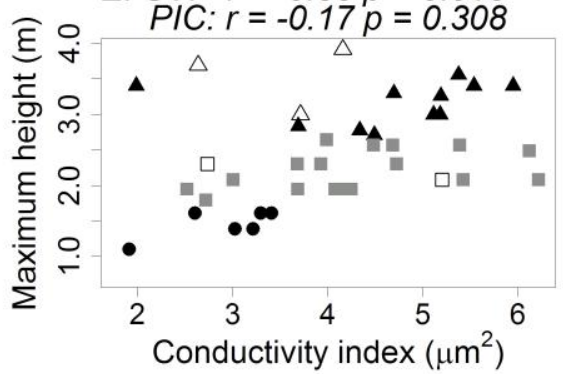


Figure S8. The influence of Leptospermum scoparium (Myrtaceae) on inferred relationships between lumen fraction and wood density. In panels $\mathrm{A}-\mathrm{C}$, the point or contrast involving Leptospermum scoparium is indicated with an arrow, with the Pearson correlation coefficient $(r)$ and probability $(p)$ for relationships between: (A) All species' values (symbols are: black triangles, canopy trees; gray squares, understory trees; black circles, shrubs; filled symbols, angiosperms; open symbols, conifers), (B) Phylogenetic independent contrasts (PICs) for all species, (C) PICs for angiosperm species only. (D) The phylogenetic tree used in comparative analyses of wood traits of all species, showing the position of the outlying contrast involving Leptospermum scoparium (marked node). 
Russo et al.

Page 36 of 36
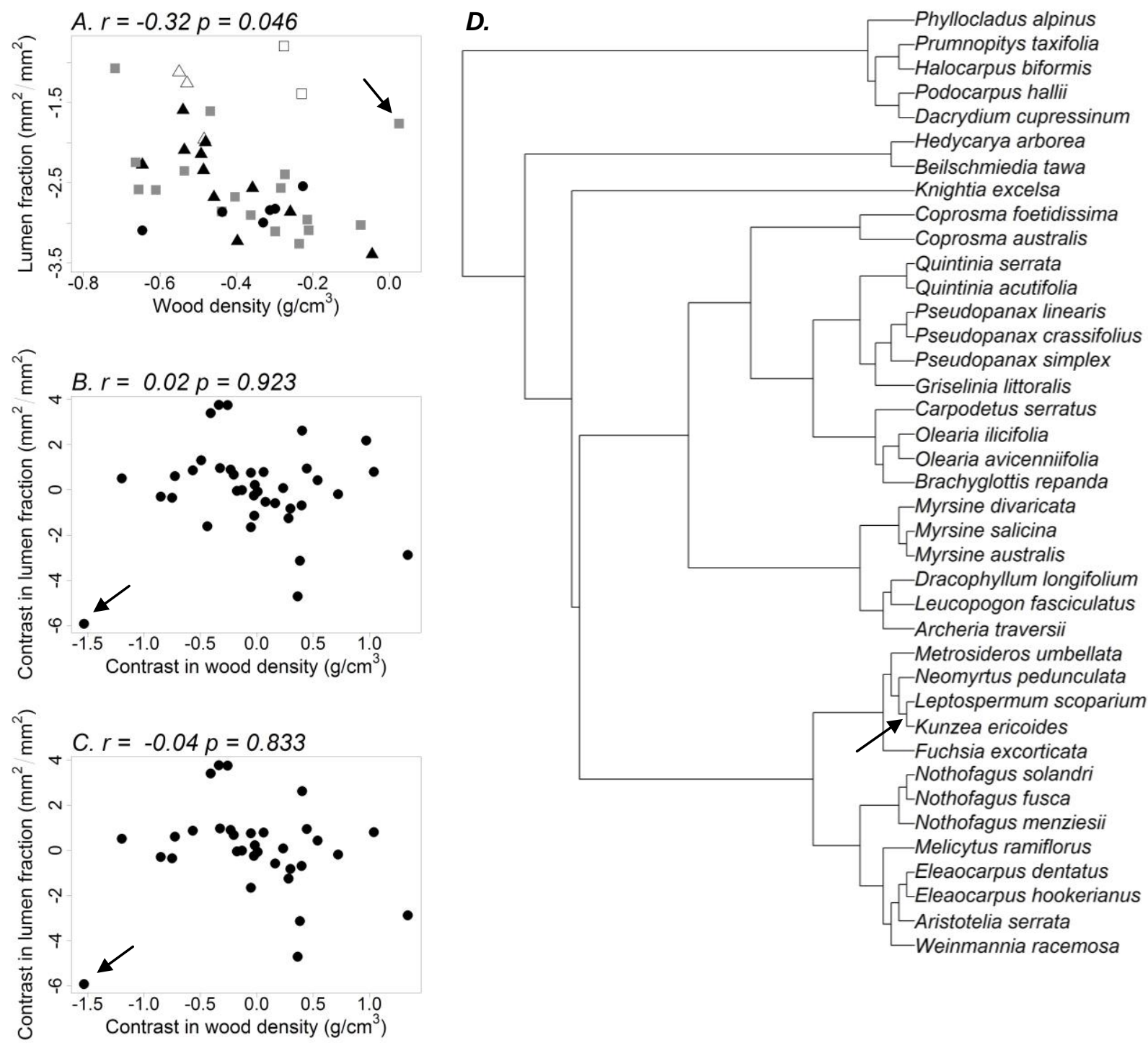